\title{
DIVERSITY AND ABUNDANCE OF HATCHED SKATE EGG CASES (CHONDRICHTHYES: ELASMOBRANCHII: RAJOIDEI) AT CASSINO BEACH, RIO GRANDE DO SUL, BRAZIL
}

\author{
Lucas de Oliveira Afonso Cordeiro \& Maria Cristina Oddone*
}

Universidade Federal do Rio Grande, Instituto de Ciências Biológicas, Setor de Morfologia/Pesquisa em Chondrichthyes, Av. Itália, Km 8 s/n, Campus Carreiros, 96203-900 Rio Grande, RS, Brasil.

${ }^{*}$ Corresponding author: mcoddone@gmail.com

\begin{abstract}
On Cassino beach, Rio Grande do Sul, Brazil, thousands of hatched cases of Rajoidei (suborder of oviparous skates) are brought by the tides being exposed on the seashore. The objective of this work was to analyze the egg cases taxonomic diversity and the occurrence frequency of the present taxa. The egg cases used in the study come from manual collections performed on the beach in two periods (corresponding to two different beach areas); between the years of 2009 and 2012, and between 2016 and 2017, in Cassino beach. The egg cases found corresponded to genera Rioraja, Sympterygia, Atlantoraja and Psammobatis. In the first period, the number of cases collected was 3050 for R. agassizi, 1180 for S. acuta, 75 for $S$. bonapartei and four for A. castelnaui. For Psammobatis extenta, $P$. rutrum, and $P$. bergi just case was in record for each one. In the second period, the number he egg cases collected was 1821 for $S$. acuta, 1681 for $R$. agassizi, 138 for $S$. bonapartei, nine for $A$. castelnaui, and a single case of $P$. rutrum. In addition, the occurrence of on egg case of Zearaja chilensis is recorded, which was found in the study area in the year 2001 .
\end{abstract}

Key words: Morphometry, Oviparity, Reproduction, Nursery areas, Southwest Atlantic, Taxonomic identification

\section{RESUMEN}

Diversidad y abundancia de capsulas ovígeras de raya (Chondrichthyes: Elasmobranchii: Rajoidei) eclosionadas en la Playa Cassino, Rio Grande do Sul, Brasil. En la playa Cassino, estado de Rio Grande do Sul, Brasil, miles de cápsulas ovígeras eclosionadas de Rajoidei (suborden de rayas ovíparas) son llevadas por la marea hacia la costa quedando depositadas en la arena. El objetivo de este trabajo fue analizar la diversidad taxonómica de estas cápsulas así como la frecuencia de ocurrencia de los taxones presentes. Las cápsulas ovígeras usadas en este estudio provienen de colectas manuales realizadas en la playa durante dos periodos (y en dos áreas diferentes): entre los años 2009 a 2012; y entre 2016 y 2017, en la playa Cassino. Las cápsulas ovígeras encontradas correspondieron con los géneros Rioraja, Sympterygia, Atlantoraja y Psammobatis. Durante el primer periodo, se colectaron un número total de 3050 cápsulas de $R$. agassizi, 1180 de S. acuta, 75 de S. bonapartei y cuatro A. castelnaui. Para el género Psammobatis, se colectó una única cápsula para cada una de las siguientes espécies: $P$. extenta, $P$. rutrum y $P$. bergi. Durante el segundo periodo, se registraron 1821 de $S$. acuta, 1681 de $R$. agassizi, 138 de S. bonapartei, nueve para $A$. castelnaui y una de $P$. rutrum. En el presente trabajo, también se registra la ocurrencia de una cápsula de $Z$. chilensis, encontrada en el área en cuestión, en el año de 2001.

Key words: Morphometric, Oviparity, Reproduction, Nursery areas, Southwest Atlantic, Taxonomic identification

\section{INTRODUCTION}

Chondrichthyes have been the subject on reproduction biology studies for more than half a millennium. In the fourth century BC, Aristotle pioneered these studies and recorded several aspects of Chondrichthyes reproduction and development, providing details on some reproductive modes, reproductive anatomy, and also on the Rajoidei egg cases (Bodson, 1983; Wourms \& Demski, 1993; Wyffles, 2009).

In this sense, the egg case is a crucial tool in the study of the oviparous species taxonomy and phylogenetics. Ishiyama $(1950,1958)$ has shown that the egg case has species-specific characteristics and is as important in understanding the phylogenetic relationships of rajoids as the clasper anatomy. The latter has been traditionally considered to differentiate among species, -especially within taxonomically complex genera; difficult to identify to species level (Menni, 1971, 1972) - because presenting specific species characteristics (Hubbs \& Ishiyama, 1968, Ebert \& Davis, 2007; Oddone \& Vooren, 2008; Ishihara et al., 2012). The importance of the egg case in taxonomy has been demonstrated through the development of dichotomous keys to identify them at the species level. This have been carried out in different regions of the world; Ishiyama (1958) for the Japan Sea, Bor (1998) for the North Sea, Oddone \& Vooren (2008) and Mabragaña et al. (2011) in the Southwestern Atlantic, Gordon et al. (2016) in the Celtic Sea, Treolar et al. (2006) in the Tasman Sea. Besides the importance 
that the egg cases may have for the researcher as a valuable taxonomic tool in the identification, in recent years, attention has been given to the occurrence of hatched (and consequently empty) rajoid egg cases deposited on the tide line in beaches. This is because, in general, the occurrence of such egg cases can be used as an indirect indicator of geographical locations of species occurrence and even possible oviposition periods and nursery areas, constituting a rich information source for the management of the species involved (Gordon et al., 2016).

Studies on the collection and identification of skate egg cases at the beachside are scarce in the literature. Gordon et al. (2016) studied the taxonomy of rajoids and cat sharks (Scyliorhinidae: Gill, 1862) through an egg cases collection program on the British coast («The Great Eggcase Hunt»), where ordinary citizens were invited to participate in the survey by collecting egg cases on the beach. On Cassino beach, a large number of rajoid empty cases are brought ashore by the tides, being exposed at the tide line. However, to date, such an occurrence has never been assessed quantitatively or qualitatively. Thus, the objective of this work is to analyze the taxonomic diversity of Rajoidei egg cases that occur in Cassino beach, and to calculate the occurrence relative frequency by genus or species.

\section{MATERIAL AND METHODS}

\section{Study area}

Cassino Beach $\left(32^{\circ} 10^{\prime} \mathrm{S}, 52^{\circ} 05^{\prime} \mathrm{W}\right)$ is located in the southernmost part of Brazil, in the Rio Grande Sul state, being part of the Southern Brazilian Coastal Ecosystem, Southwest Atlantic Ocean. It is characterized by an extensive sandy belt of about 230 $\mathrm{km}$ in length. Along this length, the beach characteristics vary between dissipative and reflective and it suffers seasonal influence of strong winds and undulations by the southeast and south of the Atlantic Ocean (Calliari et al., 2001).

\section{Collection of egg cases}

The egg cases used in this project come from collections made between the years of 2009 and 2012 on Cassino beach. The cases were collected manually, walking on the beach in a $\sim 1 \mathrm{~km}$ range, from the lemanjá statue (32011'13.3”S 52009'21.9”W) towards the Altair Ship, which is stranded in the Cassino Beach since June of 1976 (32017'30.0"S $\left.52^{\circ} 15^{\prime} 37.3^{\prime \prime} \mathrm{W}\right)$. The collections were carried out in the region located between the tide line and the dunes. In addition, new collections were made from October 2016, in the region located between the

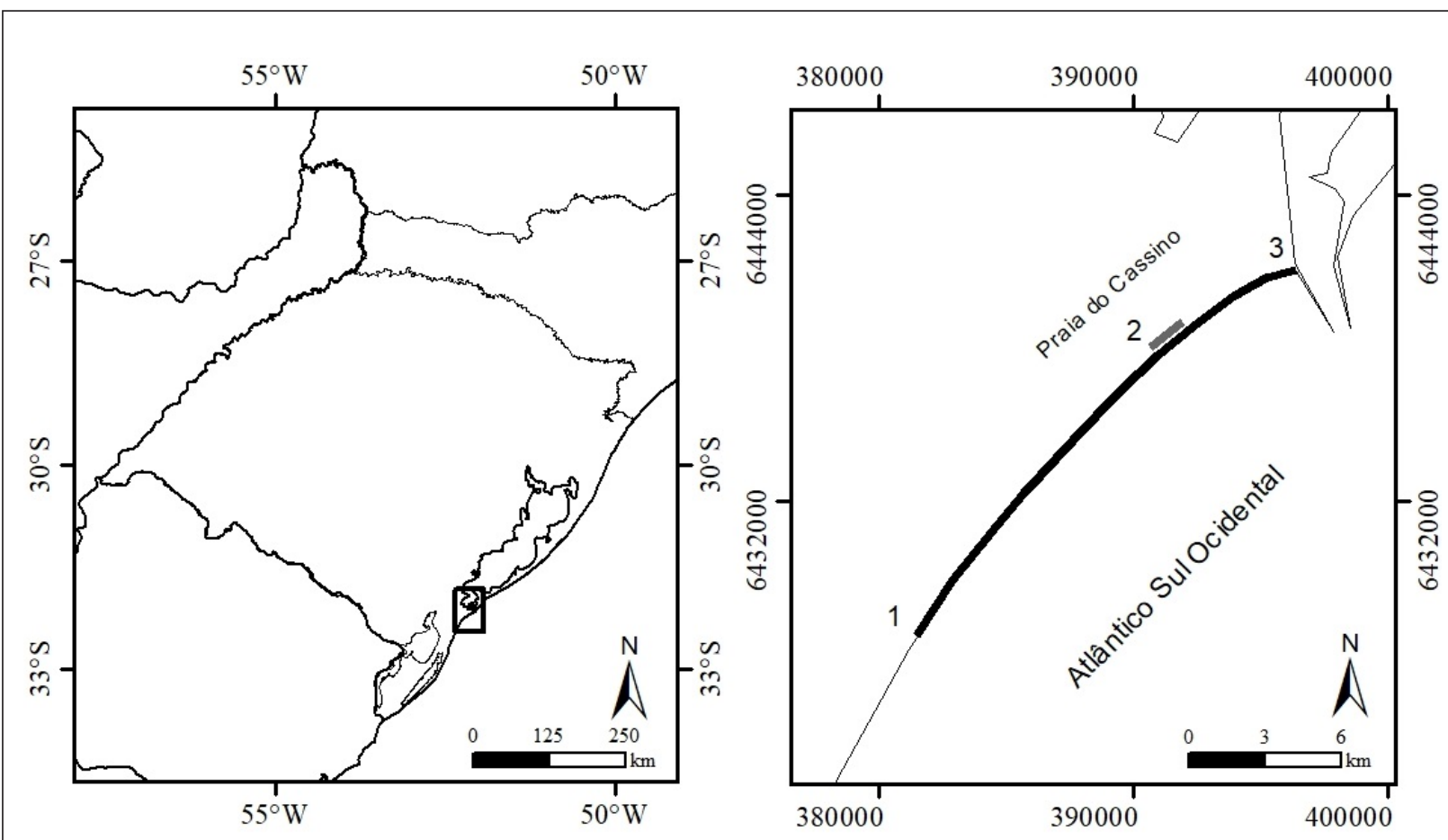

Fig. 1. Map of the study area: on the left, the state of Rio Grande do Sul and on the right, a detail of Casino beach where the collections of Rajoidei egg cases were carried out. The two collection areas are indicated with the black and gray lines above the tide line. The gray line indicates the collection area of the first period (2009-2012) of $1.0 \mathrm{~km}$ long from the lemanja statue (2) towards the Altair Ship (1). The black line indicates the collection area of the second period (2016-2017), situated between Altair Ship and the Molhes da Barra (*), more specifically, the Molhe Oeste (3). UTM 22S Coordinate System - DATUM SIRGAS 2000. 
Molhes da Barra and the Altair Ship, totaling a distance of $22 \mathrm{~km}$. In the latter case, the sampling was done in areas of $1.0 \mathrm{~km}$ on foot, in alternation with distances of $3.0 \mathrm{~km}$ by car, between the tide line and the dunes. Thus, in the present study, two collection areas are considered (Fig. 1). The Iemanjá statue and the Altair ship, as well as the Molhes da Barra, are both beach points with touristic connotation. In 2001, during non-periodic collection of egg cases in Cassino beach, an unusual case was found, whose occurrence remained unpublished until the present. In this study, the finding of this egg case is also documented, and its probable taxonomic identification is discussed. The collection site of this case corresponds to that of the period 2009 and 2012, and the same was identified based on Paesch \& Oddone (2008). Because it is a single occurrence in almost two decades, this case was not included in any calculation. The sampling effort during this study was not standardized.

\section{Biological and morphometric sampling}

After the collection, the cases were taken to the Morphology II Laboratory, Morphology sector, ICB/ FURG, for analyses. The egg cases were properly cleaned and identified according to Oddone \& Vooren (2008) and Mabragaña et al. (2011), the latter specifically for genus Psammobatis Günther, 1890. After identification, the egg cases were measured in total length (TL) and total width (TW), according to Hubbs \& Ishiyama (1968) with the aid of a Vernier caliper. The precision considered in linear measurements was $0.1 \mathrm{~mm}$. Accessory case structures such as horns and/or tendrils were not considered in the measurements, since most of the egg cases presented total or partial loss of these structures.

\section{Data analysis}

Although the total number of egg cases was higher for the 2009-2012 period, the morphometric analyzes by species were performed exclusively considering the cases collected between 2016-2017. The reason was that the cases of the 2009-2012 period were collected and measured by several samplers, which resulted in more inaccurate measurements and error. As a result, a considerable variation in the cases morphometric measurements was observed. For the 2016-2017 period, on the other hand, the cases were collected and measured by the same sampler (the first author). The coefficient of variation $(C V)$, defined as $C V=s / X$ (where $s$ is the standard deviation and $X$ is the mean) was then calculated, because it expresses the relative variability of the sample mean (Zar, 2010). The CV values for the morphometric variables recorded (taking the TL as reference, because it is less variable than the TW) of the 2009-2012 period and the 20162017 period were compared statistically, with calculated values of 20 and 16 , respectively. Although a priori the value of 16 in 2016-2017 showed a greater homogeneity in the data, the statistical comparison indicated that the CVs of both periods were statistically different $(p<0.05)$. For the egg cases of each taxon, the results were presented including a brief reference on the geographic distribution, bibliographical references of the antecedents in the literature for each species, if any, and the material examined. The egg cases are stored in Chodrichthyes Colletion of the Laboratory of Morphology II, Research in Chondrichthyes, placed in plastic bags and with the date of collection (lot CC25).

The descriptive statistics calculated for the morphometric variables followed Triola (2005). The parametric and non-parametric tests were chosen by testing the normality and homogeneity of the variance of the variables, using the Lilliefors and Levene tests, respectively (Sokal \& Rohlf, 1995). In the analyses, the level of significance (p) considered was 0.05 . Descriptive statistics were performed using PAST software (Paleontological Statistics) version 3.0 (Hammer et al., 2001). The taxonomic classification considered throughout this work was that of Compagno (2005).

\section{RESULTS}

\section{Occurrence of Rajoidei egg cases in Cassino beach}

For the 2009-2012 period a total of 4312 egg cases were collected. They corresponded to genera Rioraja Whitley, 1939, Sympterygia Müller \& Henle, 1837, Atlantoraja Menni, 1972 and Psammobatis Günther, 1890. In relation to the species, egg cases were identified as belonging to: Rioraja agassizi Müller \& Henle, 1841, Sympterygia acuta Garman, 1877, Sympterygia bonapartei Müller \& Henle, 1841, Atlantoraja castelnaui Miranda Ribeiro, 1907, Psammobatis extenta Garman, 1913, P. rutrum Jordan, 1891 and $P$. bergi Marini, 1932. The number of cases collected was 3050 for $R$. agassizi (70.30\%), 1180 for S. acuta (27.31\%), 75 for S. bonapartei (1.73\%), four for $A$. castelnaui $(0.09 \%)$, and a single egg case for each of the three Psammobatis species (Table 1, Figs. 2 and 3).

For the 2016-2017 period, a total of 3620 egg cases were collected. These cases corresponded to the same genera recorded in the previous period. In relation to the species, egg cases were identified as belonging to $S$. acuta, $R$. agassizi, S. bonapartei, $A$. castelnaui and $P$. rutrum. The number of cases collected was 1821 for $S$. acuta (50.30\%), 1681 for R. agassizi (46.43\%), 138 for S. bonapartei (3.81\%), 
Table 1. Number of Rajoidei egg cases collected monthly between October 2009 and November 2012 at Cassino beach in an area of $1 \mathrm{~km}$ in length from the statue of lemanjá towards the Altair Ship. The total numbers per month and by species are presented. The absence of field collection in a given month is indicated (-). The egg cases were identified at the species level as Sympterygia acuta, $S$. bonapartei, Rioraja agassizi and Atlantoraja castelnaui, Psammobatis extent, $\quad$ P. rutrum and P. bergi.

\begin{tabular}{|c|c|c|c|c|c|c|c|c|c|}
\hline & & S. acuta & S. bonapartei & R. agassizi & A. casteunaui & P. extenta & P. rutrum & P. bergi & TOTAL \\
\hline \multirow[t]{13}{*}{2009} & January & - & - & - & - & - & - & - & - \\
\hline & February & - & - & - & - & - & - & - & - \\
\hline & March & - & - & - & - & - & - & - & - \\
\hline & April & - & - & - & - & - & - & - & - \\
\hline & May & - & - & - & - & - & - & - & - \\
\hline & June & - & - & - & - & - & - & - & - \\
\hline & July & - & - & - & - & - & - & - & - \\
\hline & August & - & - & - & - & - & - & - & - \\
\hline & September & - & - & - & - & - & - & - & - \\
\hline & October & 29 & 1 & 77 & 0 & 1 & 0 & 0 & 108 \\
\hline & November & 20 & 0 & 27 & 0 & 0 & 0 & 0 & 47 \\
\hline & December & 54 & 0 & 19 & 0 & 0 & 0 & 0 & 73 \\
\hline & Total & 103 & 1 & 123 & 0 & 1 & 0 & 0 & 228 \\
\hline \multirow[t]{13}{*}{2010} & January & - & - & - & - & - & - & - & - \\
\hline & February & - & - & - & - & - & - & - & - \\
\hline & March & - & - & - & - & - & - & - & - \\
\hline & April & - & - & - & - & - & - & - & - \\
\hline & May & - & - & - & - & - & - & - & - \\
\hline & June & 61 & 6 & 73 & 0 & 0 & 0 & 0 & 140 \\
\hline & July & 36 & 0 & 49 & 0 & 0 & 0 & 0 & 85 \\
\hline & August & 56 & 1 & 51 & 0 & 0 & 0 & 0 & 108 \\
\hline & September & 34 & 0 & 28 & 0 & 0 & 0 & 0 & 62 \\
\hline & October & 37 & 2 & 147 & 1 & 0 & 0 & 0 & 187 \\
\hline & November & 117 & 4 & 531 & 0 & 0 & 1 & 0 & 653 \\
\hline & December & 57 & 0 & 89 & 0 & 0 & 0 & 0 & 146 \\
\hline & Total & 398 & 13 & 968 & 1 & 0 & 1 & 0 & 1380 \\
\hline \multirow[t]{13}{*}{2011} & January & 65 & 2 & 90 & 0 & 0 & 0 & 0 & 157 \\
\hline & February & 105 & 2 & 72 & 0 & 0 & 0 & 0 & 179 \\
\hline & March & 53 & 2 & 124 & 0 & 0 & 0 & 0 & 179 \\
\hline & April & 47 & 0 & 91 & 0 & 0 & 0 & 0 & 138 \\
\hline & May & 75 & 8 & 388 & 3 & 0 & 0 & 0 & 474 \\
\hline & June & 59 & 8 & 329 & 0 & 0 & 0 & 0 & 396 \\
\hline & July & 102 & 14 & 291 & 0 & 0 & 0 & 1 & 408 \\
\hline & August & 61 & 2 & 153 & 0 & 0 & 0 & 0 & 216 \\
\hline & September & 58 & 20 & 225 & 0 & 0 & 0 & 0 & 303 \\
\hline & October & 10 & 2 & 97 & 0 & 0 & 0 & 0 & 109 \\
\hline & November & 10 & 2 & 30 & 0 & 0 & 0 & 0 & 42 \\
\hline & December & 1 & 0 & 6 & 0 & 0 & 0 & 0 & 7 \\
\hline & Total & 646 & 62 & 1896 & 3 & 0 & 0 & 1 & 2608 \\
\hline \multirow[t]{13}{*}{2012} & January & 2 & 0 & 9 & 0 & 0 & 0 & 0 & 11 \\
\hline & February & - & - & - & - & - & - & - & - \\
\hline & March & - & - & - & - & - & - & - & - \\
\hline & April & 1 & 0 & 0 & 0 & 0 & 0 & 0 & 1 \\
\hline & May & 1 & 0 & 2 & 0 & 0 & 0 & 0 & 3 \\
\hline & June & - & - & - & - & - & - & - & - \\
\hline & July & - & - & - & - & - & - & - & - \\
\hline & August & 0 & 0 & 9 & 0 & 0 & 0 & 0 & 9 \\
\hline & September & 3 & 0 & 11 & 0 & 0 & 0 & 0 & 14 \\
\hline & October & 7 & 0 & 10 & 0 & 0 & 0 & 0 & 17 \\
\hline & November & 1 & 0 & 6 & 0 & 0 & 0 & 0 & 7 \\
\hline & December & - & - & - & - & - & - & - & - \\
\hline & Total & 15 & 0 & 47 & 0 & 0 & 0 & 0 & 62 \\
\hline \multicolumn{2}{|l|}{ TOTAL } & 1162 & 76 & 3034 & 4 & 1 & 1 & 1 & 4278 \\
\hline
\end{tabular}



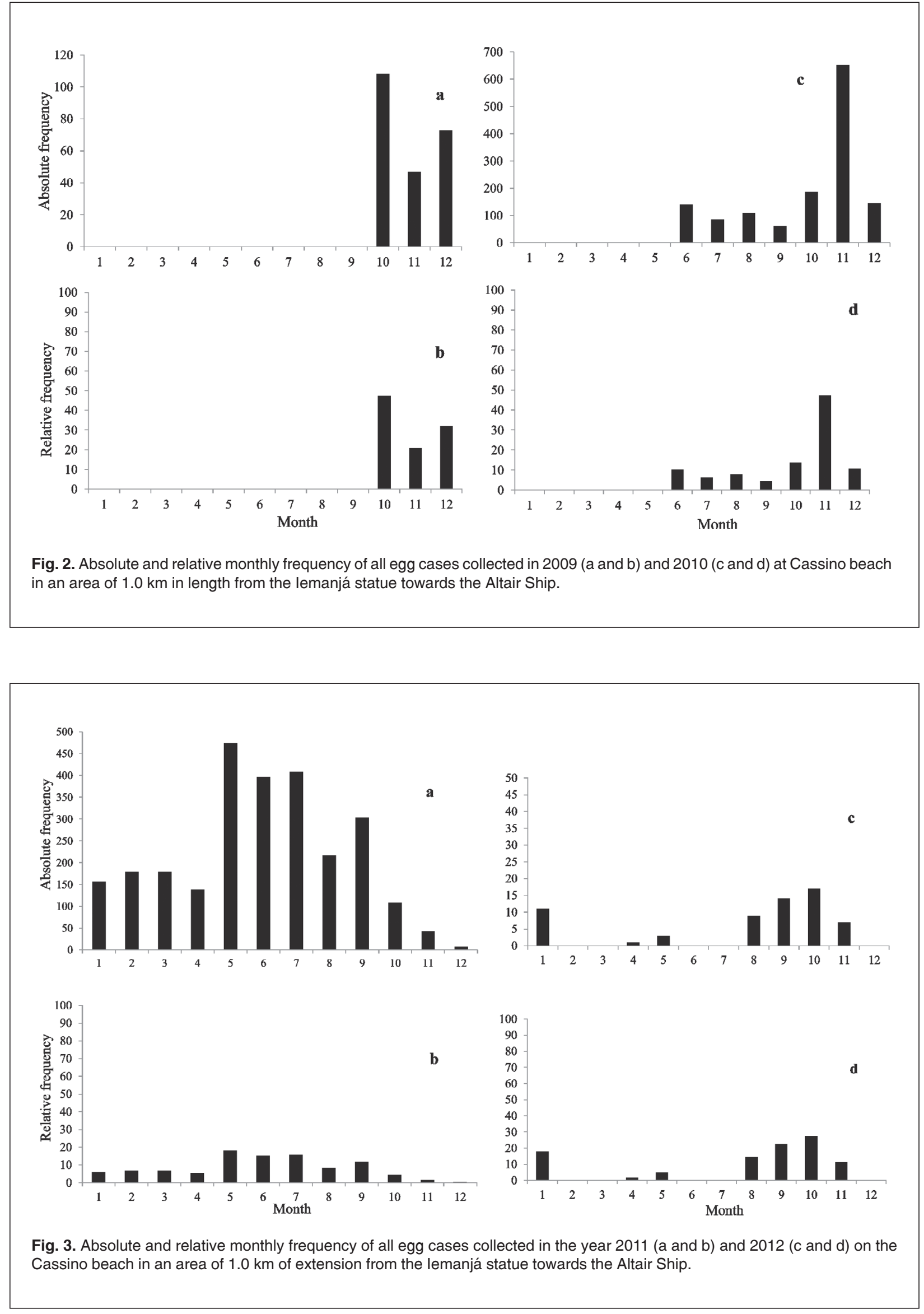

Bol. Soc. Zool. Uruguay (2ª época). 2019. Vol. 28 (2): 38-58 ISSN: 0255-4402 
nine for $A$. castelnaui, $(0.24 \%)$ and one of $P$. rutrum (Table 2, Fig. 4).

\section{Occurrence of egg cases of the genus Sympterygia Müller \& Henle, 1837 Sympterygia acuta Garman, 1877}

Distribution: Sympterygia acuta is an endemic species to the Southwest Atlantic and is distributed between Brazil and Argentina. In southern Brazil it can be found up to $60 \mathrm{~m}$ depth but is commonly found up to 30 meters (Queiroz, 1986; Vooren, 1998).

Material examined: For the first period (20092012), 1180 cases of $S$. acuta were collected, while for the second period (2016-2017) 1821 egg cases were collected. The mean TL was $3.79 \mathrm{~cm}$ and the mean TW was $2.70 \mathrm{~cm}$. The TL and TW ranges varied between 2.1 and $6.0 \mathrm{~cm}$ and between 1.9 and $3.9 \mathrm{~cm}$, respectively (Table 3, Fig. 5-8). Sympterygia acuta, as the other members of the genus, shows a unique reproductive strategy that is the construction of egg cases nests (Fig. 10).

References: Queiroz (1986) records egg cases of $S$. acuta for the southern region of Brazil and provides information on the external morphology and on the substrates types used for the construction of the nests. Oddone \& Vooren (2002) provided information and detailed descriptions of this species egg cases, incubation period in aquaria and size at birth. Brandt (2006) studied the embryonic development normal stages in $S$. acuta in the area in question. References on the occurrence of $S$. acuta egg cases on Cassino beach and their taxonomic features are presented by Oddone \& Vooren (2008). Mabragaña et al. (2011) include this species in the identification key of egg cases for the Southwest Atlantic.

\section{Synmpterygia bonapartei Müller \& Henle, 1841}

Distribution: Sympterygia bonapartei is an endemic skate of the Southwest Atlantic and can be found between Brazil (Rio de Janeiro) and Argentina (Santa Cruz) (Figueiredo, 1977; Menni \& Stehmann, 2000). Pequeño \& Lamilla $(1985,1993)$ record S. bonapartei on the southern coast of Chile, Eastern Pacific.

Material examined: For the first period (20092012), 75 cases of $S$. bonapartei were collected (Table 1, Fig. 9 and 10). Mean TL was 5.94, while the mean TW was 3.82. For the second collection period (2016-

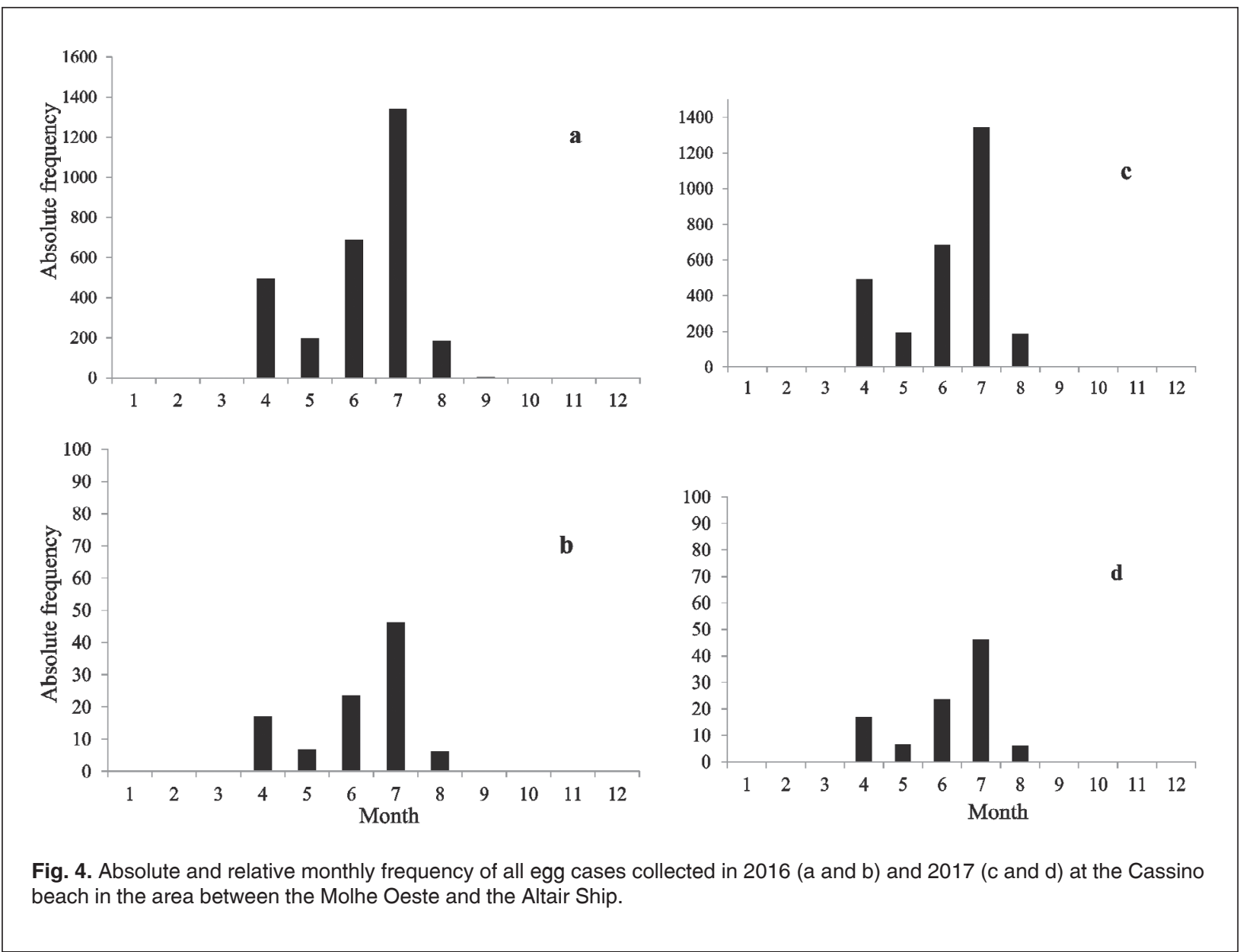

Bol. Soc. Zool. Uruguay (2ª época). 2019. Vol. 28 (2): 38-58 ISSN: 0255-4402 
Table 2. Number of Rajoidei egg cases collected monthly between October 2016 and September 2017 at Cassino beach in the area between the Molhes da Barra (Molhe Oeste) and the Altair Ship. The total numbers per month and by species are presented. The absence of field output in a given month is indicated (-). The egg cases were identified at the species level as Sympterygia acuta, S. bonapartei, Rioraja agassizi and Atlantoraja castelnaui and Psammobatis rutrum.

$\begin{array}{llll}\text { S. acuta S. bonapartei R. agassizi casteunaui Putrum TOTAL } & \text { A. }\end{array}$

\begin{tabular}{|c|c|c|c|c|c|c|c|}
\hline \multirow[t]{13}{*}{2016} & January & - & - & - & - & - & - \\
\hline & February & - & - & - & - & - & - \\
\hline & March & - & - & - & - & - & - \\
\hline & April & - & - & - & - & - & - \\
\hline & May & - & - & - & - & - & - \\
\hline & June & - & - & - & - & - & - \\
\hline & July & - & - & - & - & - & - \\
\hline & August & - & - & - & - & - & - \\
\hline & September & - & - & - & - & - & - \\
\hline & October & 144 & 48 & 146 & 0 & 0 & 338 \\
\hline & November & - & - & - & - & - & - \\
\hline & December & 208 & 23 & 146 & 1 & 0 & 378 \\
\hline & TOTAL & 352 & 71 & 292 & 1 & 0 & 716 \\
\hline \multirow[t]{13}{*}{2017} & January & - & - & - & - & - & - \\
\hline & February & - & - & - & - & - & - \\
\hline & March & - & - & - & - & - & - \\
\hline & April & 267 & 12 & 212 & 0 & 1 & 492 \\
\hline & May & 144 & 12 & 39 & 1 & 0 & 196 \\
\hline & June & 284 & 23 & 378 & 1 & 0 & 686 \\
\hline & July & 675 & 44 & 620 & 3 & 0 & 1342 \\
\hline & August & 39 & 6 & 136 & 2 & 0 & 183 \\
\hline & September & 2 & 1 & 2 & 0 & 0 & 5 \\
\hline & October & - & - & - & - & - & - \\
\hline & November & - & - & - & - & - & - \\
\hline & December & - & - & - & - & - & - \\
\hline & TOTAL & 1411 & 98 & 1387 & 7 & 1 & 2904 \\
\hline TOTAL & & 1763 & 169 & 1509 & 8 & 1 & 3450 \\
\hline
\end{tabular}

Table 3. Descriptive statistics based on total length (TL) and total width (TW) of egg cases of Sympterygia acuta, S. bonapartei, Rioraja agassizi and Atlantoraja castelnaui and Psammbatis rutrum collected monthly between October 2016 and September 2017 on the beach of Cassino in an area between the Molhes da Barra (Molhe Oeste) and the Altair Ship. For each species, sample number ( $\mathrm{n}$ ), amplitude (minimum and maximum), mean, standard error (SE), variance, standard deviation, median and variation coefficient (CV).

\begin{tabular}{|c|c|c|c|c|c|c|c|c|c|c|}
\hline & \multicolumn{2}{|c|}{ R. agassizi } & \multicolumn{2}{|c|}{ S. acuta } & \multicolumn{2}{|c|}{ S. bonapartii } & \multicolumn{2}{|c|}{ P. rutrum } & \multicolumn{2}{|c|}{ A. castelnaui } \\
\hline & $\mathrm{TL}$ & TW & $\mathrm{TL}$ & TW & TL & TW & $\mathrm{TL}$ & TW & TL & TW \\
\hline N & 1681 & 1681 & 1821 & 1821 & 137 & 137 & 1 & 1 & 9 & 9 \\
\hline Minimum & 3.2 & 2.2 & 2.1 & 1.9 & 4.3 & 2.8 & 2.20 & 1.50 & 8.2 & 6.4 \\
\hline Maximum & 6.9 & 5 & 6 & 3.9 & 8 & 5 & 2.20 & 1.50 & 10.4 & 8 \\
\hline Mean & 5.28 & 3.26 & 3.79 & 2.70 & 6.20 & 4.9 & - & - & 9.32 & 6.95 \\
\hline SE & 0.01 & 0.01 & 0.01 & 0.01 & 0.06 & 0.4 & - & - & 0.23 & 0.16 \\
\hline Variance & 0.20 & 0.13 & 0.40 & 0.14 & 0.58 & 0.24 & - & - & 0.48 & 0.25 \\
\hline SD & 0.44 & 0.36 & 0.63 & 0.37 & 0.76 & 0.49 & - & - & 0.69 & 0.50 \\
\hline Median & 5.30 & 3.30 & 3.6 & 2.7 & 6 & 4.1 & - & - & 9.03 & 6.95 \\
\hline CV & 8.39 & 11.16 & 16.66 & 13.82 & 12.36 & 12.12 & - & - & 7.44 & 7.26 \\
\hline
\end{tabular}




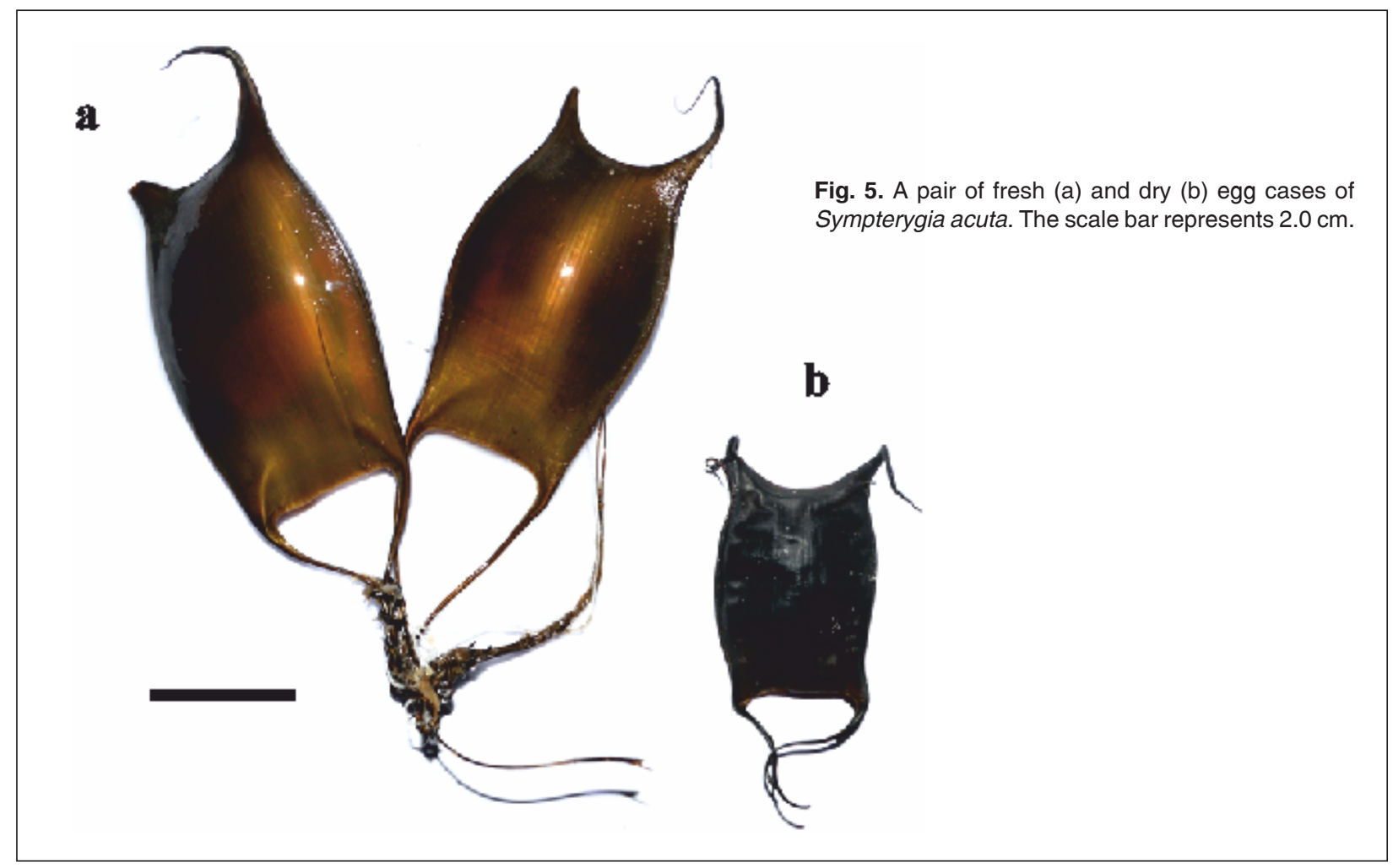

2017), 138 cases were collected, with a mean TL of 6.20 and a mean TW of 4.9. The TL range varied from 4.3 to $8 \mathrm{~cm}$ while the TW from 2.8 to $5 \mathrm{~cm}$ (Table 3 ).

References: Queiroz (1986) was the first to record $S$. bonapartei egg cases for the southern region of Brazil and to provide information about the external morphology and the substrates types used to construct the nests. References on the occurrence of $S$. bonaparteiegg cases on Cassino beach are presented by Oddone \& Vooren (2008). In 2009, Jañez \& Sueiro provided information on oviposition rates in captivity, noting that $S$. bonapartei deposits egg cases at a rate of 0.5 per day and this species is capable of depositing up to 200 egg cases per year. Mabragaña et al. (2011) include this species in the identification key of egg cases for the Southwest Atlantic.

\section{Occurrence of Rioraja agassizi egg cases Whitley, 1939}

Distribuition: Rioraja agassizi is an endemic species of the Atlantic coast of South America (Mceachran \& Aschliman, 2004, Compagno, 2005) and occurs from shallow water up to 130 meters deep (Oddone et al., 2007)

Material examined: For the $2009-2012$ period, 3050 cases of the species were collected (Table 1). For the second period (2016-2017), 1681 cases were collected (Table 2, Fig. 11 and Figs. 12-14), the mean TL and TW for these cases were 5.28 and 3.26 respectively. The minimum TL and recorded were 3.2 and 2.2; while TL and TW max were 6.9 and 5, respectively (Table 3 ).

References: The first description of the Rioraja agassizi egg cases was made at the morphological and microscopic level by Oddone et al. (2006). References on the occurrence of $R$. agassizi cases on the Cassino beach and their morphological characteristics are presented by Oddone \& Vooren (2008). Mabragaña et al. (2011) include this species in the identification key of egg cases for the Southwest Atlantic.

\section{Occurrence of egg cases of Atlantoraja castelnaui Ribeiro, 1907}

Distribution: Atlantoraja castelnaui is endemic of the Southwest Atlantic and can be found between Rio de Janeiro and northern Argentina. This species occurs at a maximum depth of $300 \mathrm{~m}$ (Oddone \& Amorim, 2007). References on the occurrence of $A$. castelnaui egg cases on the Cassino beach and their morphological characteristics are presented by Oddone \& Vooren (2008).

Material examined: $A$. castelnaui was the only species of the genus that had egg cases found on the beach, with a maximum TL of $10.4 \mathrm{~cm}$ while the smallest case found was $8.2 \mathrm{~cm}$ TL. It is important to emphasize the low number of cases found $(n=10)$, especially when compared to other species included in this study (such as S. acuta, S. bonapartei and $R$. agassizi) (Table 3, Fig. 15). 

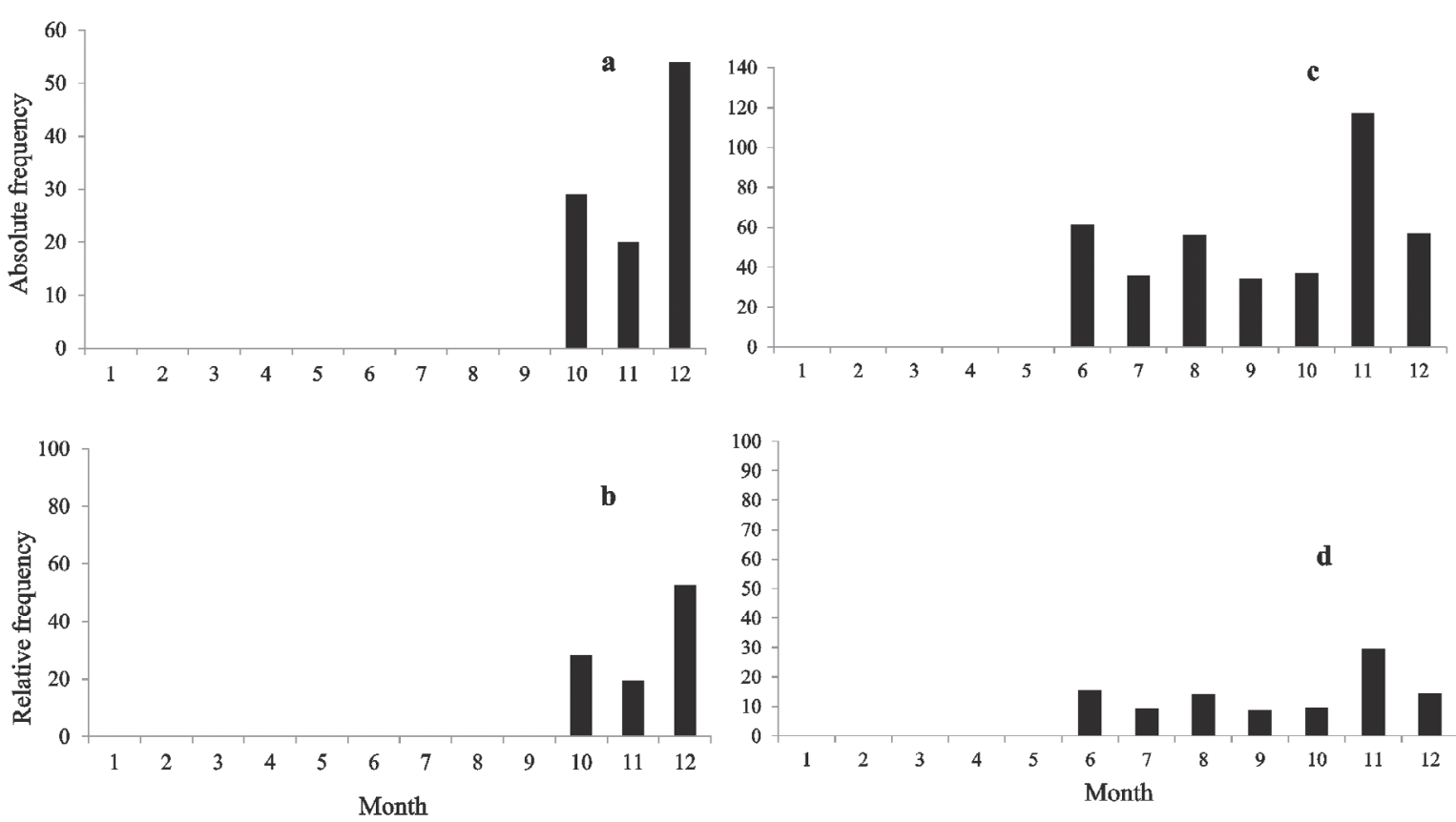

Fig. 6. Absolute and relative monthly frequency of Sympterygia acuta egg cases in the year 2009 (a and b) and 2010 (c and d) in Cassino beach, for an area of $1.0 \mathrm{~km}$ long from the lemanja statue toward the Altair Ship.

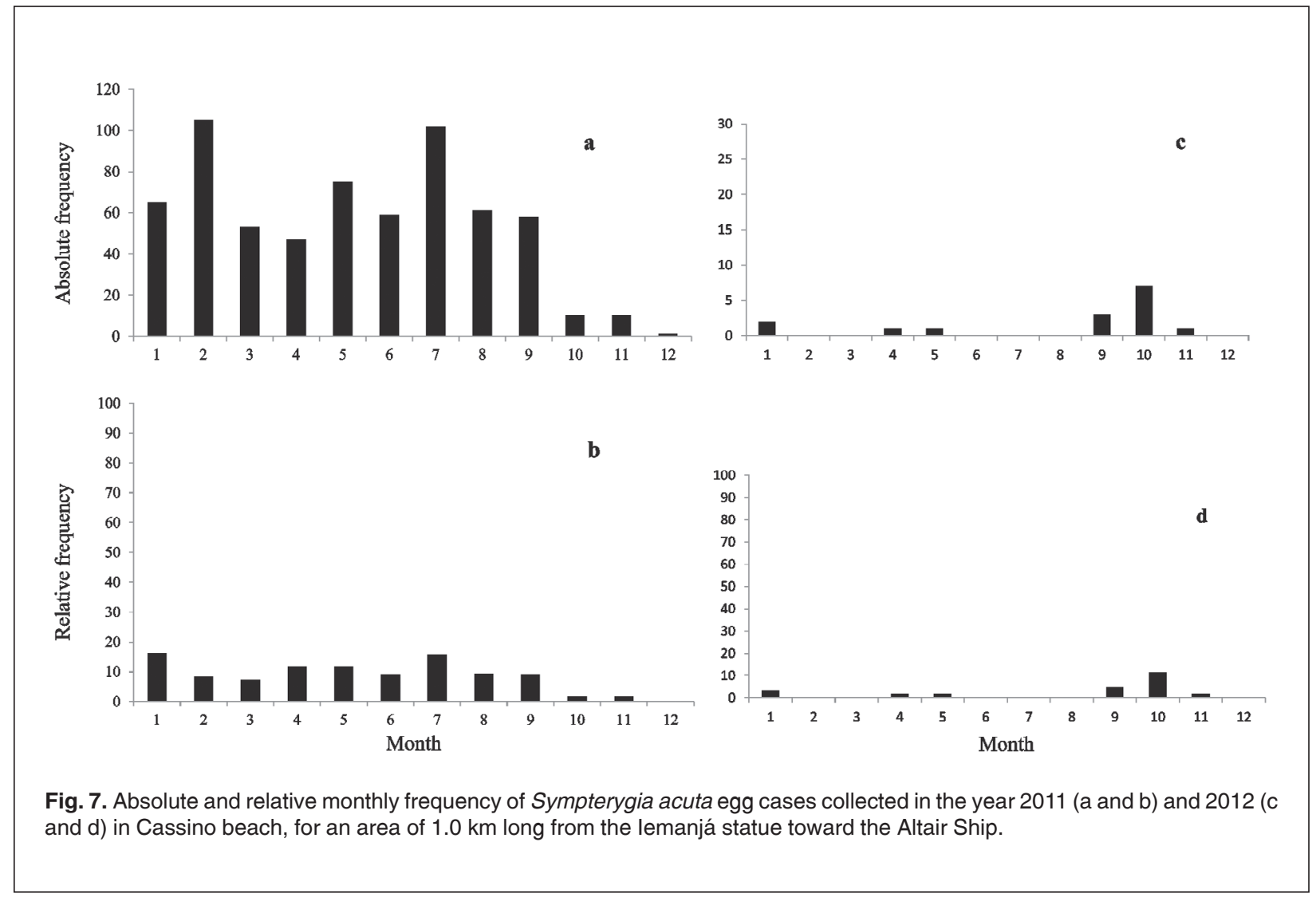

Bol. Soc. Zool. Uruguay (2ª época). 2019. Vol. 28 (2): 38-58 ISSN: 0255-4402 
References: Atlantoraja castelnaui is the largest species of the genus and one of the most common species in the coastal region of the southern Brazil, especially in relation to the egg cases. The $A$. castelnaui egg cases description was provided by Oddone et al. (2008). Reference on the occurrence of $A$. castelnaui egg cases on the Cassino beach and its morphological characteristics are presented by Oddone \& Vooren (2008). Colonello et al. (2012) studied the reproduction and provided additional information on the egg cases of this species. Mabragaña et al. (2011) include this species in the identification key of egg cases for the Southwest Atlantic.

\section{Occurrence of egg cases of the genus Psammobatis Günther, 1870 Psammobatis extenta}

Distribution: It is distributed from northern Argentina to the state of Rio de Janeiro (Chiaramonte, 2004; Gomes et al., 2010).

Material examined: Only one $P$. extenta case was collected during the study period. The case had $2 \mathrm{~cm}$ TL and $1.6 \mathrm{~cm}$ TW (Table 1, Fig. 16).

References: Mabragaña et al. (2011).

\section{Psammobatis rutrum}

Distribution: As well as $P$. extenta, it is distributed between Rio de Janeiro and northern Argentina (Kyne, 2007).

Material examined: Two $P$. rutrum cases were found, one in 2010 with TL of 2.2 and TW of 1.7, and the another in 2017, with TL of 2.2 and TW of 1.5 (Table 1 to 3, Fig. 17).

References: Mabragaña et al. (2011), Martins \& Oddone (2017).

\section{Psammobatis bergi}

Distribution: Like all the Psammobatis species present in Brazil, $P$. bergi is present from northern Argentina to Rio de Janeiro (Braccini \& Chiaramonte, 2002).

Material examined: Only one case $(n=1)$ of $P$. bergi was collected, with TL of 2.2 and $1.6 \mathrm{~cm} \mathrm{TW}$ (Table 1, Fig. 18a).

References: There is no precedent in Brazil regarding $P$. bergi case. Other references: San Martín et al. (2005), Mabragaña et al. (2011).

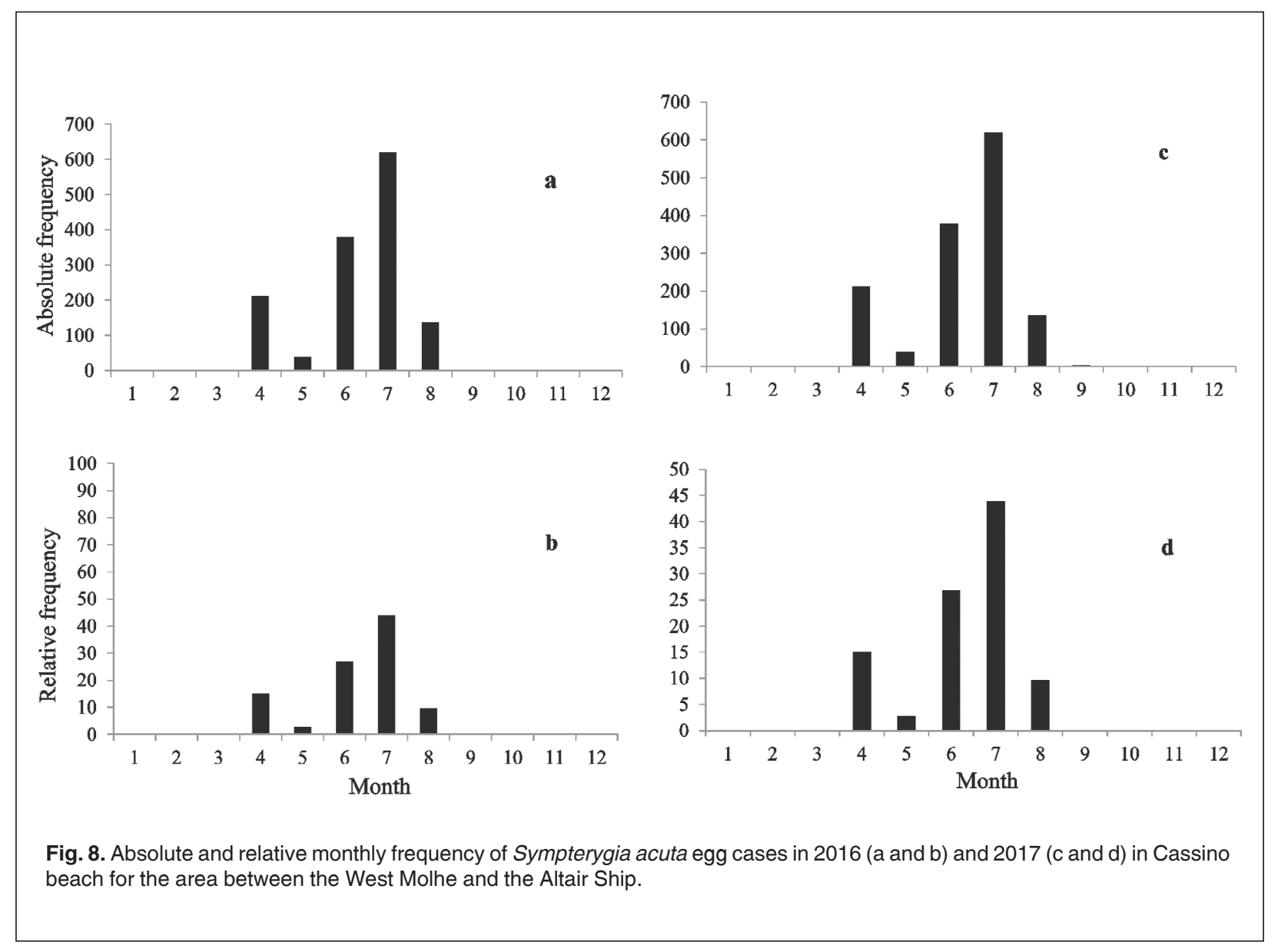

Bol. Soc. Zool. Uruguay (2ª época). 2019. Vol. 28 (2): 38-58 ISSN: 0255-4402 


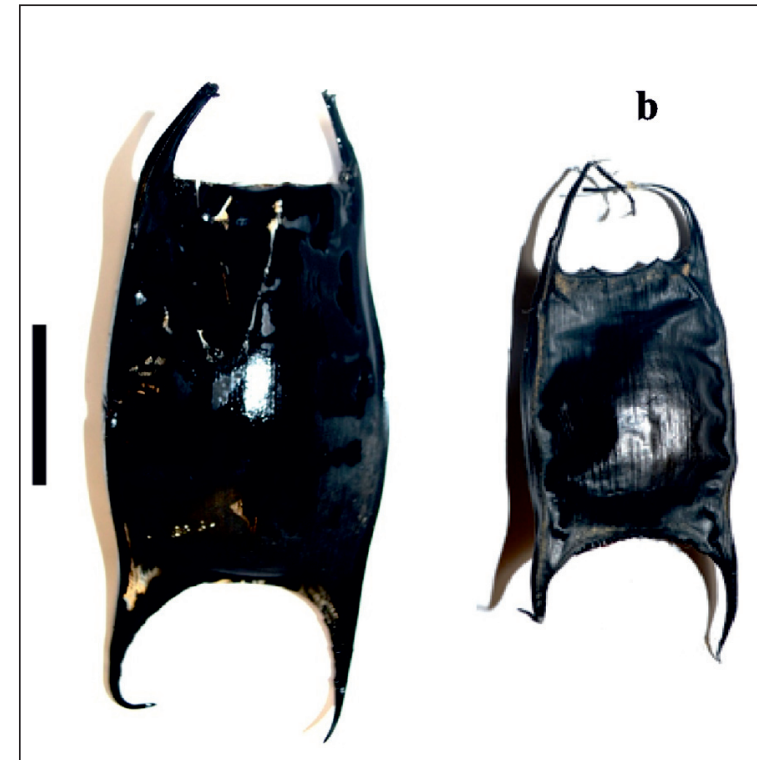

Fig. 9. Fresh (a) and dry (b) egg capsules of Sympterygia bonapartei. The posterior egg case end is oriented towards the top of the picture. The scale bar represents $3.0 \mathrm{~cm}$.

\section{Record of the occurrence of an egg case genus Zearaja Whitley, 1939}

In the year 2001, a very unusual case was found in the Cassino beach, which was identified as belonging to the genus Zearaja (Fig. 18b). It had a width of 4.0 $\mathrm{cm}$ and a length of $10.3 \mathrm{~cm}$.

\section{DISCUSSION}

The collection of hatched egg cases as an innovative approach: potential and perspectives

The skate egg cases occurrence on the Cassino beach indicates that the species involved oviposition areas are close to the coast. According to Gordon et al. (2016), oviparous elasmobranchs oviposition areas are ecologically important habitats, especially when restricted to relatively small and well-defined areas. For this reason, these authors state that knowledge about these areas, coupled with nursery areas, is crucial for the implementation of any fishery management measure related to the species involved. In this sense, it is known that the South of Brazil is a nursery area for 21 of the 27 elasmobranchs species recorded in coastal waters of the South Platform, among which are Sympterygia acuta and $S$. bonapartei (Vooren et al., 2005), contemplated in this study.

The studies that involve the collection of already hatched egg cases in beaches are very scarce, although the egg cases of the condrictes has become,

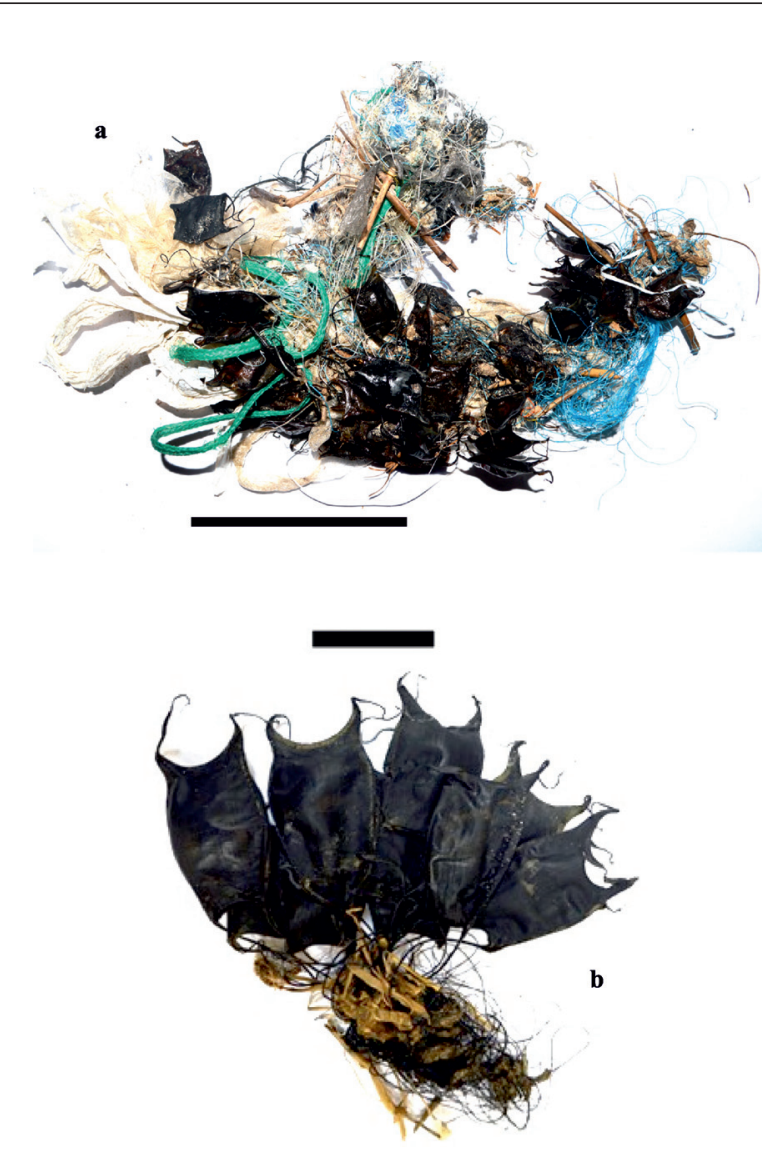

Fig. 10. (a) Skate nests composed by egg caspules of Sympterygia acuta (a) and Sympterygia bonapartei (b). The scale bars represents $10 \mathrm{~cm}$ in (a) and $3.0 \mathrm{~cm}$ in (b). Note that in (a) the egg cases were attached by the females to anthropogenic debris, like plastic bags and fishing nets and ropes. In (b) it is possible to see the extremely long egg cases tendrils firmly entangled with each other and on a rest of dry plant.

since the last decade, a frequent study element in several world regions in the context of the group's reproductive biology, including the Southwest Atlantic (eg, Oddone \& Vooren, 2008; Mabragaña et al., 2011). In general, these studies related to the egg cases address taxonomic issues related to morphology (see, for example, Ebert \& Davis 2007, Ishihara et al., 2012). It is important to note that the origin of egg cases in these studies include cases that were extracted in utero from ovate females from collection in research cruises or commercial fishing. The great advantage of these studies is to have access to the egg cases in its most intact form, from every point of view.

On the other hand, studies that include collection and identification of hatched egg cases on beaches, 


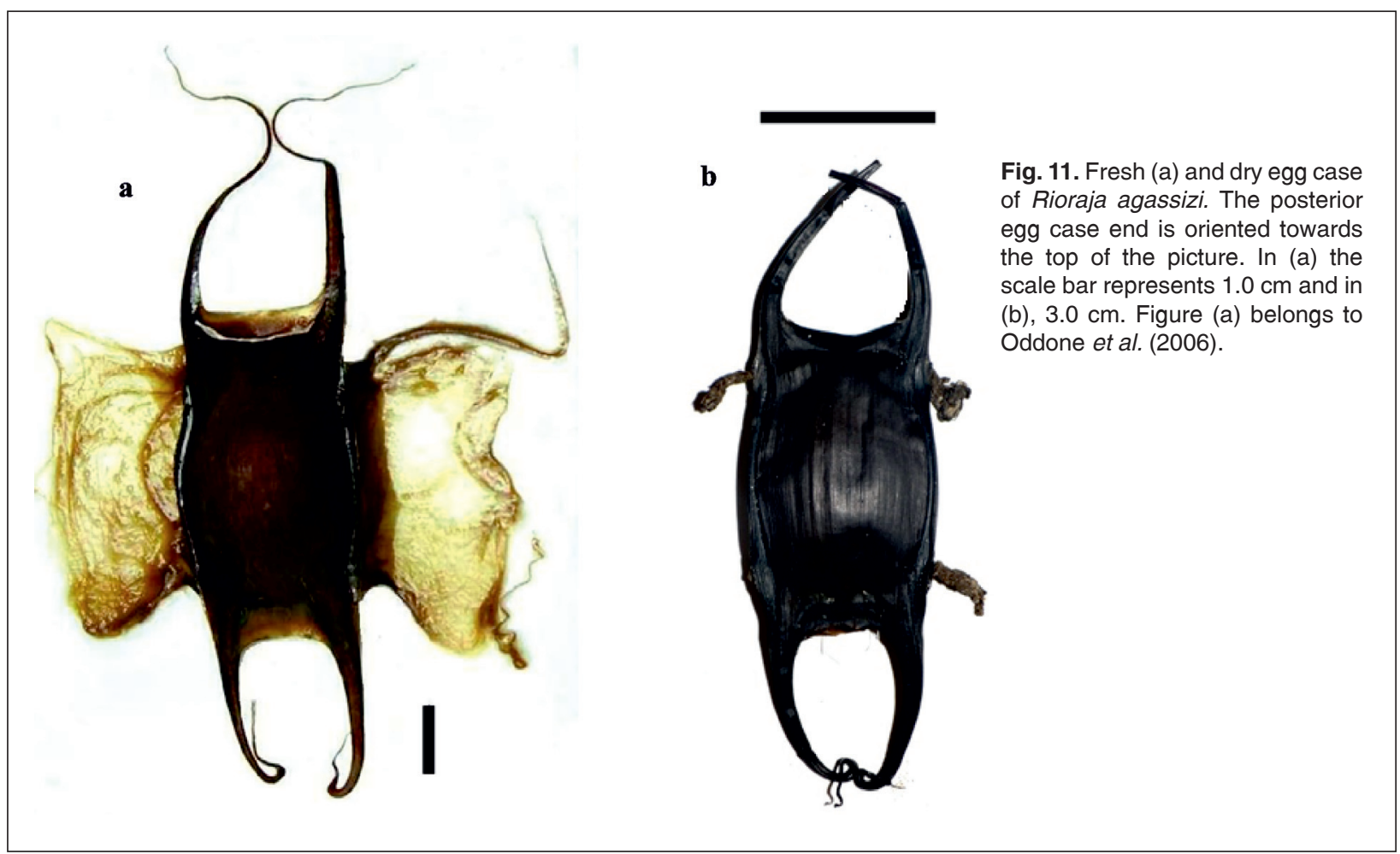

such as the present work, have recently appeared in the literature not only for skates, but also for sharks. The main work of this type that is referred to in this study is that of Gordon et al. (2016) who carried out manual collections of egg cases on British beaches in the Eastern North Atlantic, recording the presence of ten species of skates and three of sharks. For the South of Brazil, there are no published records on the occurrence of oviparous cases of oviparous sharks, although there are records of the occurrence of three oviparous species in these waters (family Scyliorhinidae Gill, 1862); Galeus mincaronei Soto, 2001, Scyliorhinus haeckelii Miranda Ribeiro, 1907 and Schroederichthys saurisqualus Soto, 2001. This is probably due, first, to the depth of occurrence of these sharks species, which is considerably higher than that of the oviparous skates, and in second, to the oviposition mode of the egg cases, which differs completely from that pattern commonly observed in the streaks, except in the genus Sympterygia, which will be discussed later. In southern Brazil, shark egg cases were only accessible through fishing prospecting cruises, as in the case of $S$. saurisqualus whose cases are deposited in corals Lophelia pertusa Linnaeus, 1758 and gorgonian, as in other oviparous sharks species (see for example, Bythaelurus canescens Günther, 1878 in the Eastern South Pacific according to Concha et al. (2010)).
Another methodology for egg cases collection and study is in situ observation through diving. In this type of studies, the egg case is already in a variable stage of embryonic development, and may have passed hours, days, weeks or months in the environment, due to the fact that, during the oviposition, the egg cases of species with simple oviparous, like skates, the embryo is in the blastoderm phase (Luer et al., 2007). For this reason, the in situ cases morphological characteristics have already undergone changes of a variable degree in relation to that extracted in utero. In the area in question, this alternative collection becomes impracticable due to water conditions, where visibility is zero. However, it is possible in certain areas of the Pacific (Concha et al., 2013, Treude et al., 2011) and this direct observation methodology fundamental to unveil oviposition behavior.

On the other hand, on the Cassino beach there is something that is not uncommon in comparison to other regions, but it is crucial, at least indirect, for the study of the reproductive behavior and the reproduction of the skates species: the occurrence of a resounding volume of already hatched egg cases on the edge of the beach. This phenomenon repeats itself year after year and to date has not been quantified or at least analyzed from a qualitative perspective. The cases exposed at the edge of the beach are empty, and the reason for this occurrence 

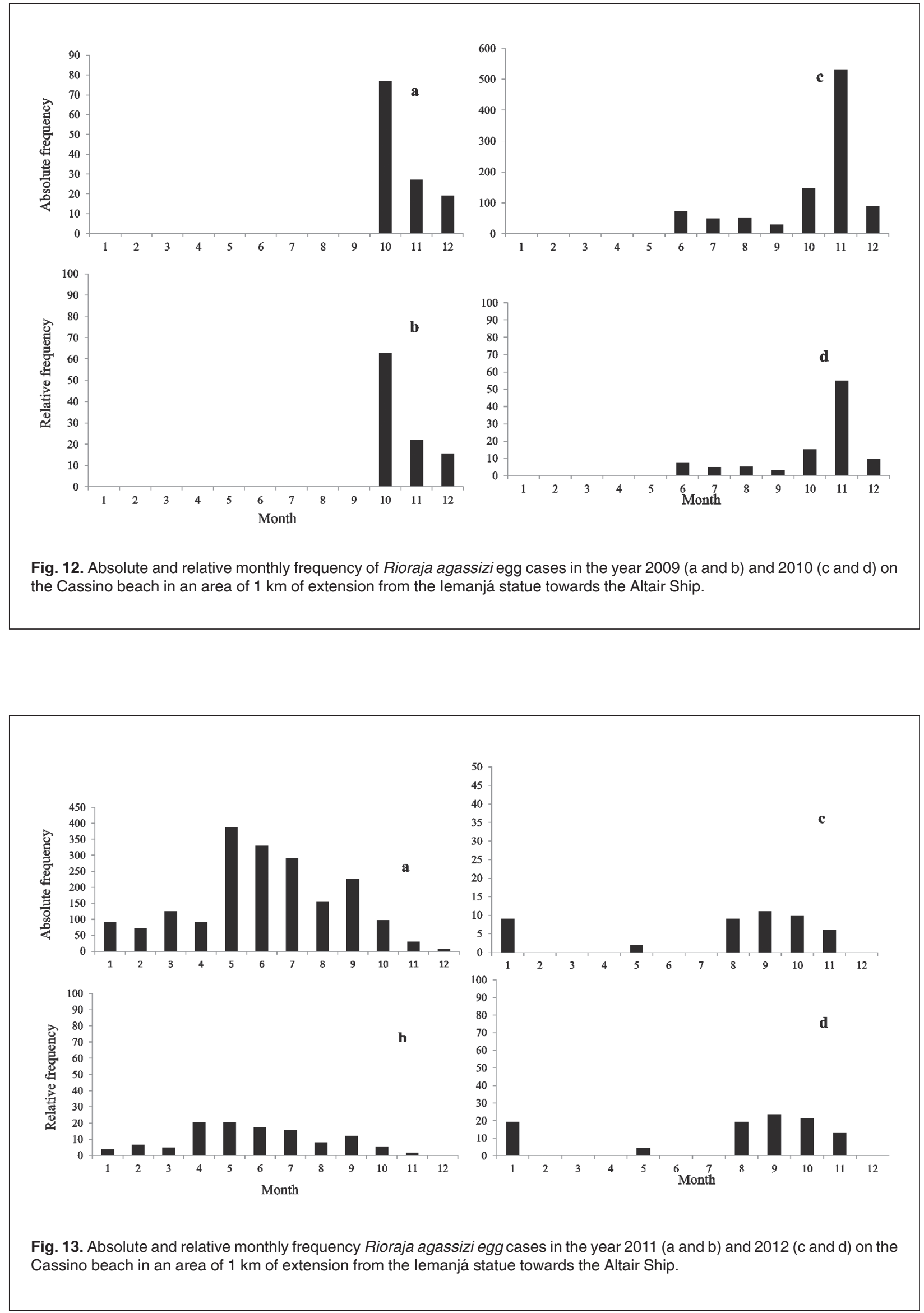

Bol. Soc. Zool. Uruguay (2ª época). 2019. Vol. 28 (2): 38-58 ISSN: 0255-4402 
is the fact that they are at the mercy of the tides for probably long periods due to their lightness.

It is difficult (or perhaps impossible) to know the time between the time of hatching and the appearance on the beach, but it is possible that a considerable period of time has passed, since the egg case is attached to the bottom or other substrates ( depending on the species) firmly by adhesion fibrils (Ebert \& Davis 2007; Oddone \& Vooren, 2008). As expected, the egg cases found at the edge of the beach present a considerable deviation from their initial condition and appearance, since the protein structure that composes them (which resembles collagen, according to Cox \& Koob, 1993) has passed, due to the time exposure to air and consequent dehydration by a gradual and irreversible drying process resulting in a radical change in color, texture and size.

For these reasons, the identification becomes more difficult, although a detailed knowledge about the details of the taxonomic importance characteristics related to the identification of egg cases, allows the discrimination between genders and still between species in the dry and empty cases. On the other hand, depending on the period of the year, the egg cases volume deposited at the beach edge can be so high that it is impossible to ignore these occurrences, as to diversity, relative abundance and seasonality. It is in this order that the main results will be discussed.

\section{The hatched egg cases occurrence as an inference tool of the taxonomic diversity}

For Southern Brazil, according to Vooren \& Oddone (2019), there are 15 species of oviparous skates; three from the Arhynchobatidae family; Atlantoraja castelnaui, Atlantoraja cyclophora Regan, 1903, Atlantoraja platana Günther, 1880, and 12 of the Rajidae family; Psammobatis bergi, Psammobatis extenta, $P$. lentiginosa McEachran, 1983, P. rutrum, Rhinoraja multispinis Norman, 1937, Rioraja agassizi, Sympterygia acuta, S. bonapartei and Dactylobatus clarki Bigelow \& Schroeder, 1958, Dipturus leptocauda Krefft \& Stehmann, 1975, Dipturus mennii Gomes \& Paragó, 2001, Gurgesiella dorsalifera McEachran \& Compagno, 1980. Most of these species are present in the continental shelf up to the $200 \mathrm{~m}$ isobath, with resident populations and with reproduction record in the area in question, except for Dactylobatus clarki occurring sporadically, and for $D$. leptocauda and Gurgesiella dorsalifera which are recorded exclusively on the continental slope between the 200 and $600 \mathrm{~m}$ isobaths.

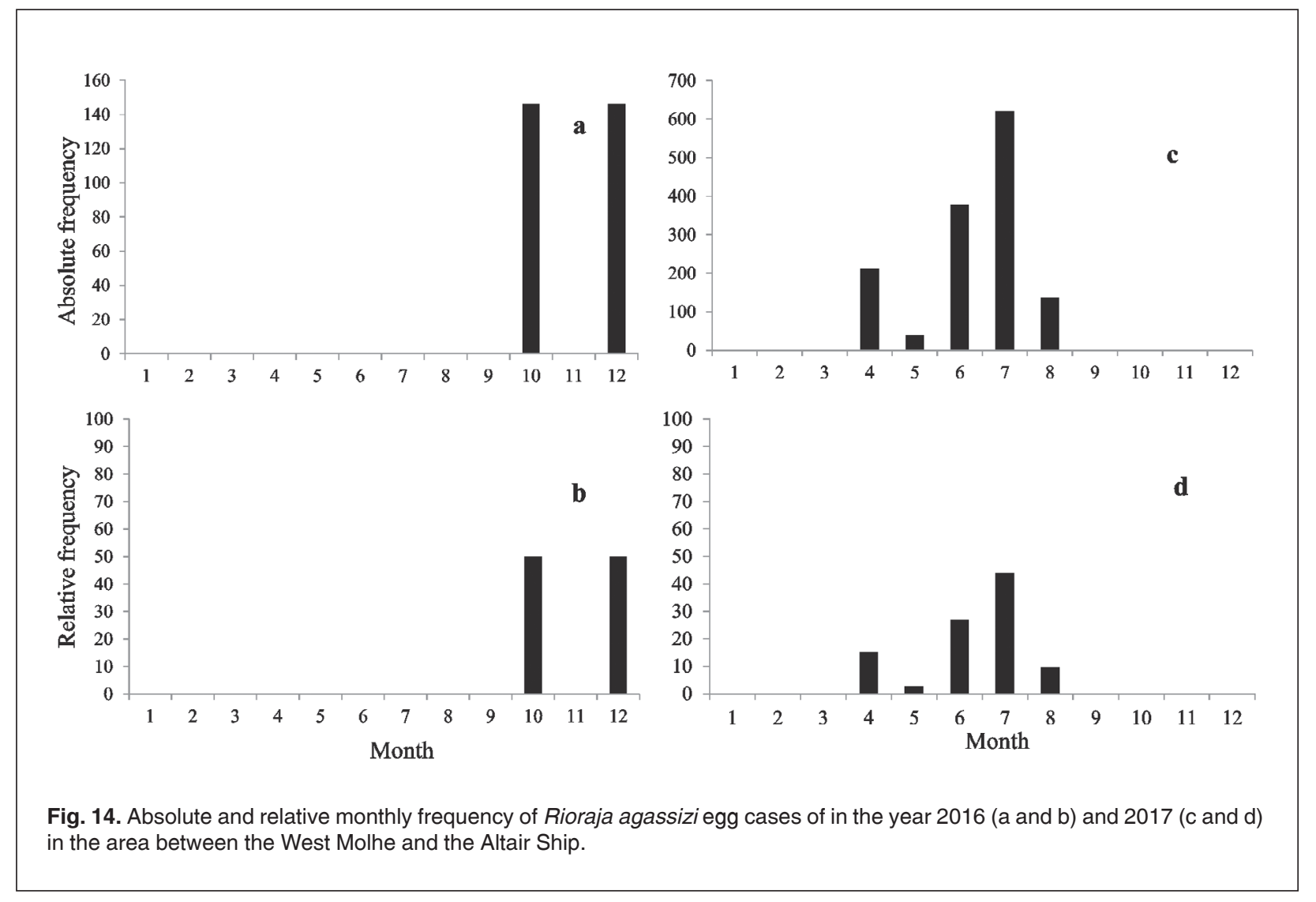

Bol. Soc. Zool. Uruguay (2ª época). 2019. Vol. 28 (2): 38-58 ISSN: 0255-4402 

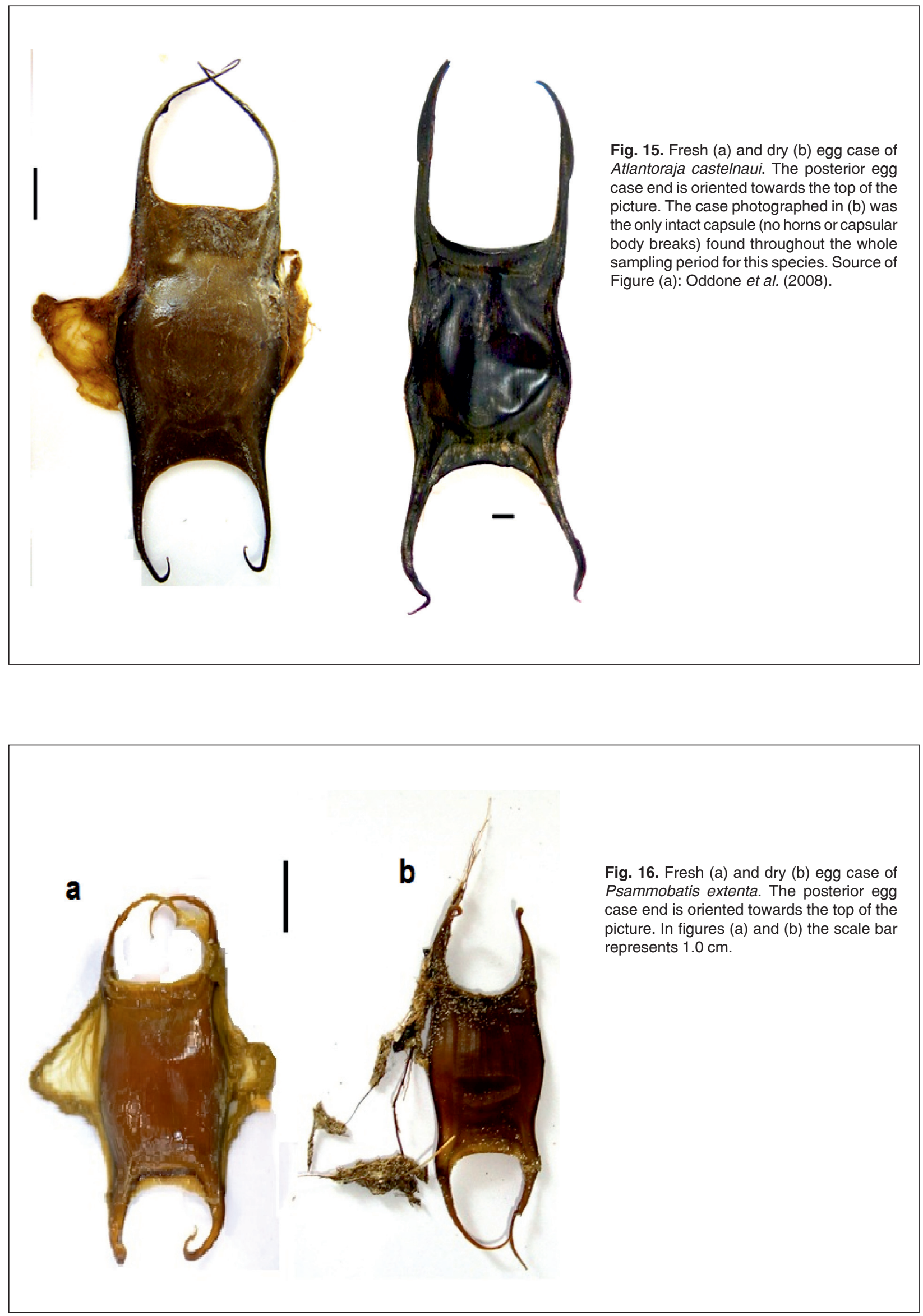

Bol. Soc. Zool. Uruguay (2ª época). 2019. Vol. 28 (2): 38-58 ISSN: 0255-4402 
According to this, it could be stated that the occurrence of skate egg cases is in fact related to the depth of occurrence of the different species (mainly with the maximum depth), since to date no egg case has been found of those species that occur on the slope. Likewise, among the species that occur on the continental shelf, it was observed that the species that were represented through the egg cases found in the beach were $S$. acuta and $S$. bonapartei, and $R$ agassizi that occur until the $50 \mathrm{~m}$ isobath (occurrence between 10 and $40 \mathrm{~m}$, according to Vooren 1998). In the other hand, the $A$. castelnaui cases were the fourth in proportional abundance, and this species is mentioned to a depth of between 30 and $180 \mathrm{~m}$, according to Vooren, 1998.

For the 2009-2012 period the egg case of $R$. agassizi was the most frequent $(70.30 \%)$, while those of $S$. acuta represented $27.31 \%$ of the total of egg cases sampled. For the $2016-2017$ period, on the other hand, egg cases of $S$. acuta represented $50.30 \%$ of the total sample of egg cases collected, with $R$. agassizi on the second place, with $46.43 \%$. In both periods, $S$. acuta and $A$. castelnaui were on third and fourth places respectively. These differences may be related to natural fluctuations of the proportion of egg bearing females both species in the area in question, or either to a patchy distribution of both species along the $16 \mathrm{~km}$ long sampling area.

Egg cases of $A$. cyclophora and $A$. platana were not in record. In the case of $A$. cyclophora, the absence could be explained by the species depth of occurrence, between 50 and $300 \mathrm{~m}$, but $A$. platana is mentioned for the depth range of between 40 and $100 \mathrm{~m}$, amplitude that is included in the occurrence areatof $A$. castelnaui, so that the cases absence of this species in the samples cannot be explained by depth. It is important to point out that the presence of $A$. platana was recorded between 100 and $150 \mathrm{~m}$ in fishing prospecting cruises on the platform and slope of South Brazil (between 100 and $600 \mathrm{~m}$ ) (Marçal, 2003). In these same cruises, A. cyclophora occurred between 100 and $300 \mathrm{~m}$, with no occurrence of Sympterygia or R. agassizi (Oddone \& Vooren, 2004).

The occurrence of Psammobatis cases was sporadic, indicating that - according to our hypothesis about occurrence versus depth - the species is not as close to the coast as those of the genus Sympterygia and Rioraja. For Braccini \& Chiaramonte (2002) P. extenta is able to reproduce throughout the year, although other aspects such as number of cases per year and incubation time remain unknown for the species. $P$. rutrum is very little known in relation to its biology and ecology (Kyne, 2007), just as $P$. extenta, but the lack of information about its reproductive cycle is a matter of concern to the understanding of the relation between depth and oviposition. San Martin et al. (2005) state that $P$. bergi has a continuous reproductive cycle throughout the year with the peak at the hottest times, however, this does not translate into the amount of cases collected on the beach. In relation to the case of Zearaja sp., due to its dimensions, it is possible that it is $Z$. chilensis, however, there is no certainty due to the high degree

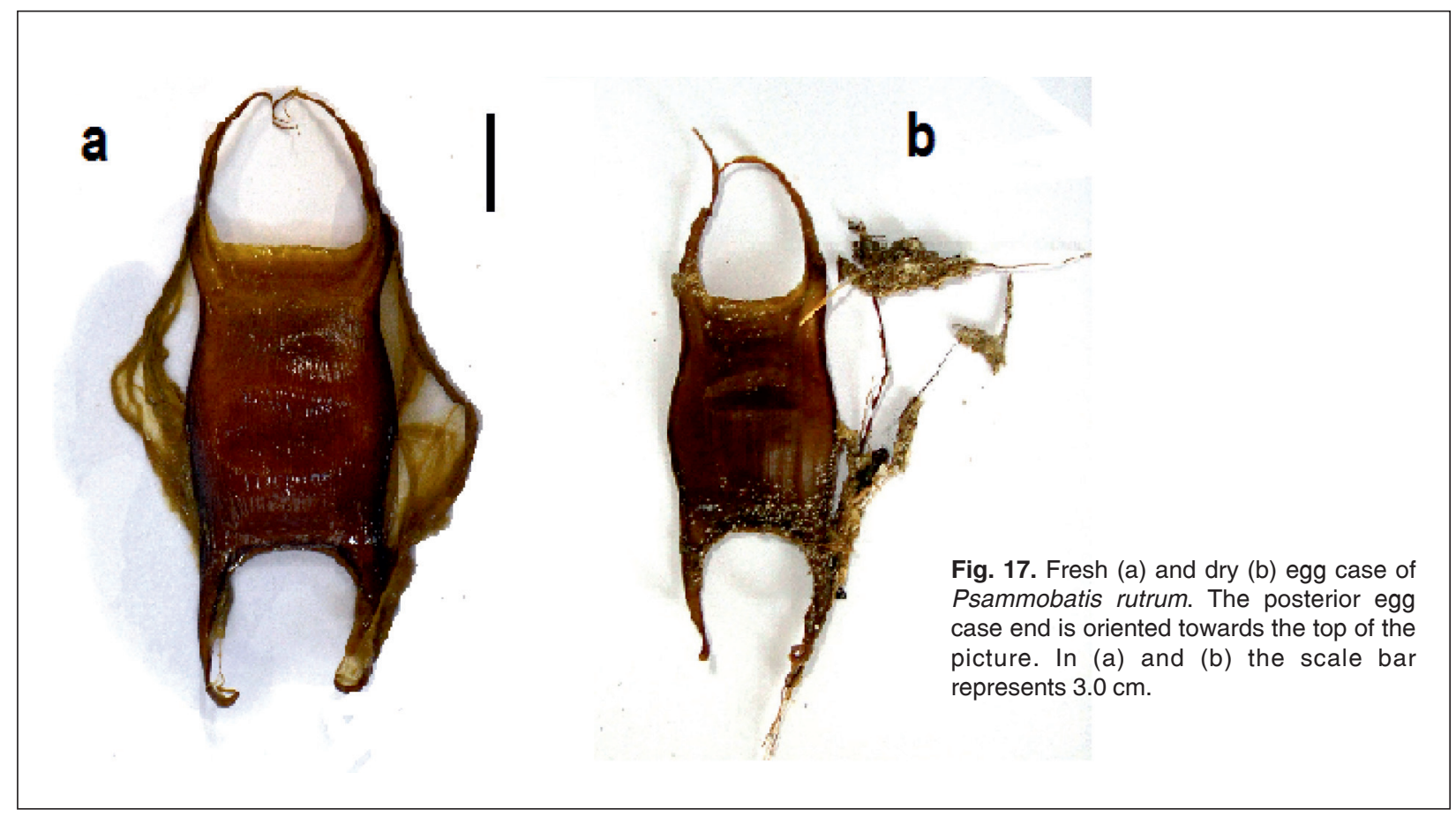

Bol. Soc. Zool. Uruguay (2ª época). 2019. Vol. 28 (2): 38-58 ISSN: 0255-4402 


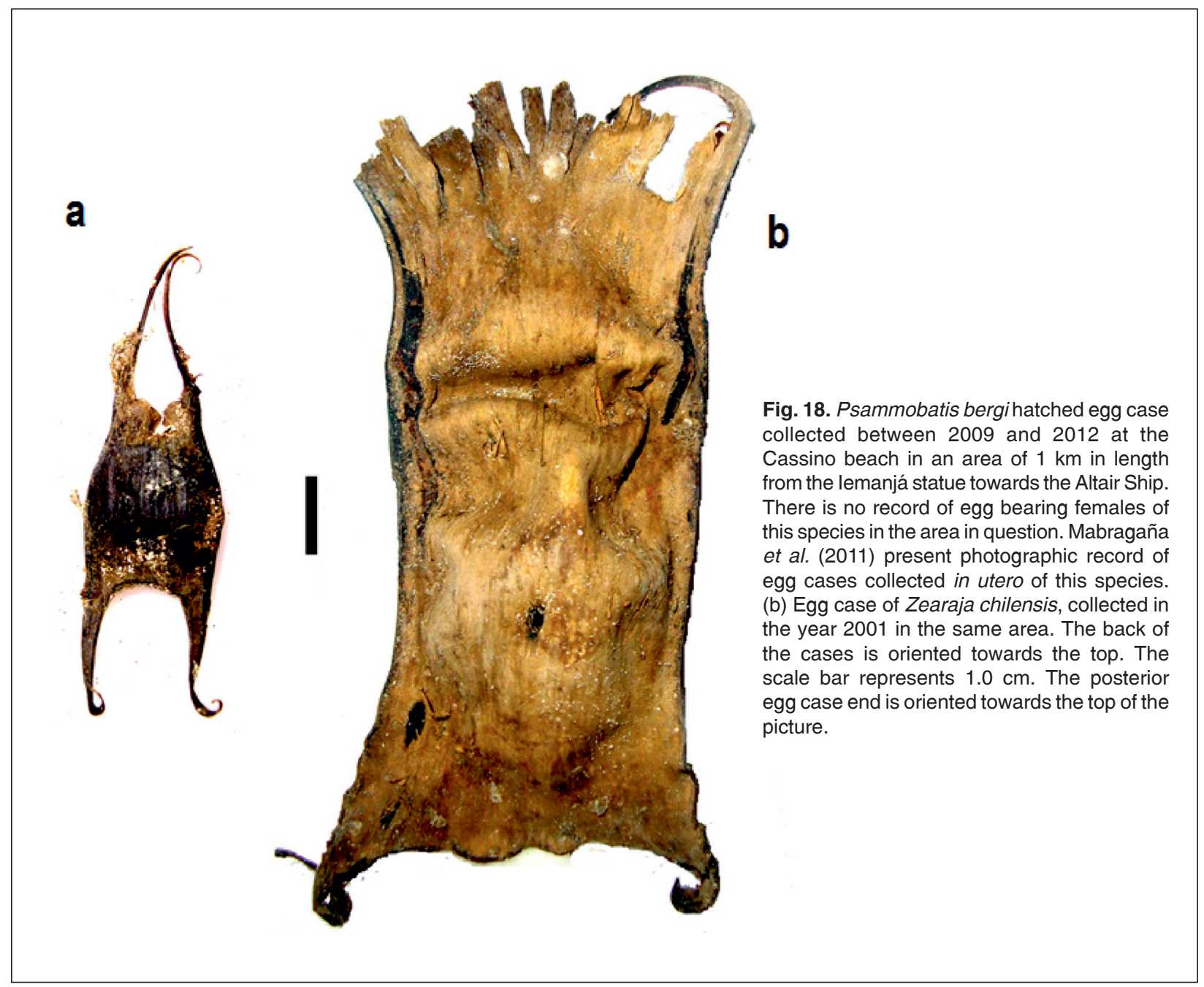

of dehydration of the same and consequent shrinkage. Even so, the geographical distribution of $Z$. chilensis coincides with the collection site (Meneses \& Paesch, 2003).

\section{The relative abundance of cases per taxon}

Coupled with depth, one must also consider the abundance of the species in the area in question. In this sense, Vooren (1998), based on the fishing prospecting cruises conducted in this area, found that in the depth range of between 10 and $100 \mathrm{~m}, \mathrm{~S}$. acuta, $S$. bonapartei and $A$. castelnaui represented (together with other viviparous species) $80 \%$ of the total biomass of demersal elasmobranchs. Attention is drawn to the absence of $R$. agassizi in this statistic, especially since it represents the most frequent species in the landings of commercial bottom trawling in the port of Rio Grande (M. C. Oddone, obs. pess.). Vooren (1998) considers that the species of elasmobranchs of the South platform can be classified based on the annual schedule of its temporal distribution in four categories. In the category «species of constant presence», the author includes the genera Sympterygia, Atlantoraja and Rioraja, however, specimens of the genus Psammobatis are not included in any classification because they are not routinely observed in the field.

Is it not possible to determine seasonal patterns of the occurrence of egg cases in this instance. Coupled to the seasonality, is the hypothesis of the relative abundance of egg ray cases, could be related to the species reproductive cycle. Egg cases were found year-round on the beach, which shows that these organisms are actually «sea-hens», as Wyffels (2009) states. This is because in fact, after reaching the sexual maturity size, reproduction is continuous throughout the female's life, with some short periods of sexual rest at the individual level (Oddone et al., 2007). However, for any of the species found it would be possible to reach definitive conclusions regarding possible periods with greater oviposition intensity, mainly due to the fact that sampling was not continuous during all months. Evaluating the oviposition seasonality 
was also not possible for the same reason as abundance: the absence of continued sampling during the study years. However, the relative proportion in species occurrence remained practically the same throughout the entire study period. It can be assumed that by $S$. acuta and $R$. agassizi the proximity to the shoreline makes it easier to carry these cases to the edge of the beach in times of rough seas. Similarly, the fact that $A$. castelnaui cases are the least frequent is related to the fact that the species inhabits greater depths (Vooren, 1988; Colonello et al., 2012).

In relation to the characteristics of egg cases with taxonomic importance, it was observed that total egg case length can discriminate a priori genera and species. This is the case of $A$. castelanui, whose case is the largest found in the region, reaching 10.4 $\mathrm{cm}$ of TL. Similarly, the cases of the genus Psammobatis are characteristic by their small size comparatively, not exceeding 2.3 of TL. The Rioraja agassizi cases have an important overlap in their TL with the cases of $S$. acuta and $S$. bonapartei. This is problematic, because when dried the cases in question can be confused by the loss of their most characteristic traits, such as the presence of a keel in the $R$. agassizi egg case, and total absence of this of the genus Sympterygia (Oddone \& Vooren, 2008). The comparison between the total length and the total width of the cases of $S$. acuta, $S$. bonapartei and $R$. agassizi revealed an interesting pattern, since there is an outstanding difference in the case size of the two species of the genus Sympterygia and this shows that the cases size can be used as an important aid in differentiating the cases of these two genera. The case of $R$. agassizi oscillates between the sizes of $S$. acuta and $S$. bonapartei, so its size measurements cannot be used as an identification factor.

Queiroz (1986) reports that S. bonapartei presents migratory behavior. Vooren (1998) states that, in fact, according to the annual timetable of its temporal distribution, $S$. bonapartei is a winter migrant species. This means that the species is distributed in the Argentine and Uruguayan waters during the summer, migrating to the winter to the continental shelf in the south. This behavior, also mentioned by Vooren \& Oddone (2019) is also known and reported by bottom trawlers skippers, who affirm that the abundance of $S$. bonapartei is related to the time of the year. Relating this to the frequency of occurrence of $S$. bonaparteiegg cases on the beach, it could be assumed that the low frequency of this species, in comparison with its $S$. acuta congener, could be associated to the absence of females ovate during the greater part of the year.

\section{The construction of nests: a unique attribute of the genus Sympterygia}

The most notable fact about the cases of the genus Sympterygia is the oviposition mode, which consists of «nests». This term was introduced by Wourms (1977) in reference to the oviposition mode of the shark Heterodontus japonicus Miklouho-Maclay \& Macleay, 1884. In the nest, a number of up to 50 egg cases can be found, according to Brant (2006). Probably, by observing the aspect of the tendrils when strongly attached to substrates of varied origin, the females tie the cases in it (see Fig. 10a). The substrates include terrestrial vegetable branches, polychaete tubes (Diopatra sp.), and Atherinidae spawns (Queiroz, 1986). In addition to terrestrial plants, we have observed the incidence of seaweed and rests of terrestrial plants (e.g., grasses) as well as conglomerates of other organisms such as mussels and all along to anthropogenic debris (Oddone \& Vooren, 2002), like plastic bags, fishing nets and ropes, and even human clothes or pieces of them (M. C. Oddone, unpublished data). Brant (2006) reported the occurrence of mixed nests, with egg cases of both S. acuta and S. bonapartei. Queiroz (1986) observed that the two species live in sympatry and this raises questions about how the oviposition of these species occurs and how they build these nests. Although there is no parental care in Chondrichthyes, the construction of a nest shows that the female is extremely careful in looking for a specific place to attach the egg cases. In this way, in spite of the fact that there is no parental care after hatching, the fact that the female seeks for a place for embryonic development to occur is considered as a degree of parental care, according to Wourms (1977). Oddone \& Vooren (2002) attribute crucial importance to the egg case tendrils at oviposition, which are coiled by females, as in the scyliorhinids (Wyffels, 2009). Such construction is only possible in the genus Sympterygia, since tendrils were not registered in any other species of skate.

\section{CONCLUSIONS}

This study represents a non-lethal method of data collection that constitutes a rich and easily accessible source of information on embryonic development and oviposition behavior of the oviparous skate species of southern Brazil. Although it was not possible to determine seasonal patterns in the egg cases occurrence, this kind of methodological approach proved to be efficient in revealing the species that occur in the area, even of those who occur sporadically or either inhabit greater depths. A long-term sampling program is needed in order to determine seasonality and infer eventual periods of more intense oviposition. In addition, this study may represent a source of information on reproductive trends and even population declines on skates through the systematic counting of hatched egg cases, since the volume of egg cases found is significant for some species such as $S$. acuta and $R$. agassizi. 


\section{ACKNOWLEDGMENTS}

The present work constituted the Undergraduate Thesis of Lucas de Oliveira Afonso Cordeiro, who was granted a scholarship of the Institutional Program of Scholarships of Scientific Initiation of the National Council of Scientific and Technological Development of the Federal University of Rio Grande (PIBIC/CNPq/ FURG) during 2016. The oceanographer Marco Antonio de Oliveira kindly provided the map of Fig. 1. Several undergraduate students participated in field work collecting egg cases in Casino Beach; in the years of 2010 and 2012 two of them were PIBIC/ CNPq/FURG scholarship holders. The comments made by Professor Juliano Marangoni (Institute of Mathematics, Statistics and Physics - IMEF - FURG) were essential for the planning of this study methodology. Dr. Ezequiel Mabragaña advised on the identification of cases of the genus Psammobatis. The data used in this work belong to the research project «Phylogenetic relationships, morphological diversity and seasonal occurrence of skate egg cases (Chondrichthyes: Batoidea) from Southern Brazil», with registration at the Pró-rectory of Research and Post-Graduation (Propesp) of FURG. This paper was translated to English by Rômulo Reginato Gabriel. Professor Carolus Maria Vooren (retired professor at the Institute of Oceanography, FURG and founder of the former "Laboratório de Elasmobrânquios e Aves Marinhas") was the main encourager of the development of a quantitative and conyinue monitoring program of the occurrence of egg cases by species over an extended period of time at Cassino beach.

\section{REFERENCES}

Bodson L. 1983. Aristotle's statement on the reproduction of sharks. Journal of the History of Biology, 16(3): 391-407.

Bor P.H.F. 1998. Eikapsels van haaien en roggen. Wetenschappen Mededelingen Koninklijke Nederlandse Natuurhistorische Vereniging, 48 pp.

Braccini J.M. \& G.E. Chiaramonte. 2002. Reproductive biology of Psammobatis extenta. Journal of Fish Biology, 61: 272-288.

Brant F.C. 2006. Morfologia e biometria do desenvolvimento embrionário da raia Sympterygia acuta Garman, 1887 (Elasmobranchii: Rajidae). Dissertação de Mestrado. Universidade Federal do Rio Grande. Rio Grande, RS.

Calliari L.J., Speranski N.S.I., Torronteguy M, \& M.B. Oliveira. 2001. The mud banks of Cassino Beach, Southern Brazil: characteristics, processes and effects. Journal of Coastal Research, 34: 318-325.
Colonello J.C., García M. L., Lasta, C.A. \& R.C. Menni. 2012. Reproductive biology of the spotback skate Atlantoraja castelnaui in the south-west Atlantic Ocean. Journal of Fish Biology, 80: 2405-2419.

Compagno L.J.V. 2005. Checklist of living Chondrichthyes. En: Hamlett, W.C. (Ed.) Reproductive biology and phylogeny of Chondrichthyes: sharks, rays and chimaeras, pp. 503-548. Vol. 3. Endfield, USA: Science Publishers.

Concha F., Morales N. \& Larraguibel J. 2013. Egg cases of the Filetail fanskate Sympterygia lima (Poeppig 1835) (Rajiformes, Arhynchobatidae) from the southeastern Pacific Ocean, with observations on captive egg-laying. Ichthyological Research, 60: 203-208.

Concha, F., Bustamante C., Oddone M.C., Hernandez S. \& J. Lamilla. 2010. Egg cases of the dusky catshark Bythaelurus canescens (Carcharhiniformes, Scyliorhinidae) from the south-eastern Pacific Ocean. Journal of Fish Biology, 77: 963-971.

Cox D.L. \& T.J. Koob. 1993. Predation on elasmobranch eggs. Environmental Biology of Fishes, 38: 117125.

Ebert D.A. \& C.D. Davis. 2007. Descriptions of skate egg cases (Chondrichthyes: Rajiformes: Rajoidei) from the eastern North Pacific. Zootaxa, 1393: 1-8.

Figueiredo J.L. 1977. Manual de peixes marinhos do sudeste do Brasil. I. Introdução. Cações, raias e quimeras. Museu de Zoologia, Universidade de São Paulo. Brasil. 104pp.

Gomes U.L., Signori C.N., Gadig O.B.F. \& H.R.S. Santos. 2010. Guia para identificação de tubarões e raias do Rio de Janeiro. Rio de Janeiro: Technical Books Editora, Rio de Janeiro. 236 pp.

Gordon C.A., Hood A.L. \& J. R . Ellis. 2016. Descriptions and revised key to the eggcases of the skates (Rajiformes: Rajidae) and catsharks (Carcharhiniformes: Scyliorhinidae) of the British Isles. Zootaxa, 4150 (3): 255-280.

Hammer Ø., Harper D.A.T., \& Ryan P.D. 2001. PAST: Paleontological Statistics software package for education and data analysis. http://palaeoelectronica.org/.

Hubbs C.L. \& R. Ishiyama. 1968. Methods for the taxonomic studies and description of skates (Rajidae). Copeia, 3: 483-491.

Ishihara H., Treolar M., Bor P.H.F., Senou H., \& C.H. Jeong. 2012. The comparative morphology of skate egg cases (Chondichthyes: Elasmobranchii: Rajiformes). Bulletin of the Kanagawa Prefectural Museum, Natural Science, 41: 17-33.

Ishiyama R. 1950. Studies on the rays and akates belonging to the family Rajidae, found in Japan and adjacent regions. Japanese Journal of Ichthyology, 1-7. 
Ishiyama R. 1958. Observations on the eggs-cases of skates of the Family Rajidae, found in Japan and its adjacent waters. Bulletin of the Museum of Comparative Zoology at Harvard College Bulletin of the Museum of Comparative Zoology at Harvard College, 18(1).

Jañez J. A. \& M. Sueiro. 2009. Oviposition rate of the fanskate Sympterygia bonapartii (Elasmobranchii, Rajidae) (Müller \& Henle, 1841) held in captivity. Panamerican Journal of Aquatic Sciences, 4(4): 580-582.

Kyne P.M. 2007. Psammobatis rutrum. The IUCN Red List of Threatened Species 2007: e.T63101A12603797.

Luer C.A., Walsh C.J., Bodine A.B. \& J.T. Wyffels. 2007. Normal embryonic development in the clearnose skate, Raja eglanteria, with experimental observations on artificial insemination. Environmental Biology of Fishes, 80(2): 239-255.

Mabragaña E., Figueroa D.E., Scenna L.B., Díaz de Astarloa J.M., Colonello J.H. \& G. Delpiani. 2011. Chondrichthyan egg cases from the southwest Atlantic Ocean. Journal of Fish Biology, 79: 1261-1290.

Martins M. F. \& M. C. Oddone. 2017. Reproductive biology of Psammobatis rutrum (Chondrichthyes: Arhynchobatidae) in south Brazil, south-west Atlantic. Journal of Fish Biology, 91(2): 443-459.

Marçal A.S. 2003. Biologia reprodutiva de Atlantoraja platana (Günther 1880) (Elasmobranchii: Rajidae) no Sul do Brasil. Dissertação de Mestrado. Universidade Federal de Rio Grande. Rio Grande, RS.

McEachran J.D. \& N. Aschliman. 2004. Phylogeny of Batoidea. En: Carrier J.C., Musick J.A. \& Heithaus M.R. (Eds.). Biology of sharks and their relatives, pp. 79-113. CRC Press, LLC, Boca Raton, Florida.

Meneses P. \& L. Paesch. 2003. Guía de campo para la identificación de peces cartilaginosos en el Río de la Plata y su frente oceánico. Frente Marítimo, 19: 137-185.

Menni R.C. 1971. Anatomia del mixopterigio y posicion sistematica de Raja (Dipturus) flavirostris Phillipi 1892. Neotropica, 17(52): 39-43.

Menni R.C. 1972. Anatomia del mixopterigio y diferencias especificas en los géneros Psammobatis y Sympterygia (Chodrichthyes, Rajidae). Neotropica, 18(56); 73-80.

Menni R.C. \& F.W. Stehmann. 2000. Distribution, environment and biology of batoid fishes off Argentina, Uruguay and Brazil. A review. Revista del Museo Argentino de Ciencias Naturales Bernardino Rivadavia e Instituto Nacional de Investigación de las Ciencias Naturales, 2: 69109.
Oddone M.C. \& C.M. Vooren. 2002. Egg cases and size at hatching of Symptergia acuta in the south-western Atlantic. Journal of Fish Biology, 61: 858-861.

Oddone M.C. \& C.M. Vooren. 2004. Distribution, abundance and morphometry of Atlantoraja cyclophora (Regan, 1903) (Elasmobranchii: Rajidae) in southern Brazil, Southwestern Atlantic, Neotropical Ichthyology, 2(3): 137-144.

Oddone M.C. \& C.M. Vooren. 2008. Comparative morphology and identification of egg cases of skate species of the genera Atlantoraja Menni, 1972, Rioraja Whitley, 1939 and Sympterygia, Müller \& Henle, 1837. Arquivos de Ciências do Mar, 41(2): 5-13.

Oddone M.C., Mesa A. \& A.F. Amorim. 2006. The egg capsule of Rioraja agassizi (Müller \& Henle, 1841) (Elasmobranchii, Rajidae), endemic to the SW Atlantic. Panamerican Journal of Aquatic Sciences, 1(2): 43-48.

Oddone M.C., Amorim A.F., Mancini P.L., Norbis W. \& G. Velasco. 2007. The reproductive biology and cycle of Rioraja agassizii (Müller \& Henle, 1841) (Chondrichthyes: Rajidae) in southeast Brazil, SW Atlantic Ocean. Scientia Marina, 71(3): 593-604.

Oddone, M.C., Mesa, A. \& A.F. Amorim. 2008. Description of the egg capsule of Atlantoraja castelnaui (Elasmobranchii, Rajidae). Brazilian Journal of Oceanography, 56(1): 65-68.

Paesch L. \& M.C. Oddone. 2008. Change in size-atmaturity of the yellownose skate Dipturus chilensis (Guichenot, 1848) (Elasmobranchii: Rajidae) in the SW Atlantic. Neotropical Ichthyology, 6: 223-230.

Pequeño G. \& J. Lamilla. 1985. Estudio sobre una colección de rayas del sur de Chile (Chondrichthyes, Rajidae). Revista de Biología Marina y Oceanografía, 21(2): 225-271.

Pequeño G. \& J. Lamilla. 1993. Batoídeos comunes a las costas de Chile y Argentina-Uruguay (Pisces: Chondrichthyes). Revista de Biología Marina y Oceanografía, 28(2): 203-217

Queiroz E.L. 1986. Estudo comparativo da alimentação de Sympterygia acuta Garman, 1877 e S. bonapartei Müller e Henle, 1841 (Pisces: Rajiformes) com relação a distribuição, abundância, morfologia e reprodução nas águas litorâneas do Rio Grande do Sul - Brasil. Dissertação de Mestrado. Universidade Federal do Rio Grande. Rio Grande, RS

San Martín M.J., Perez J.E. \& G.E. Chiaramonte. 2005. Reproductive biology of the South West Atlantic marbled sand skate Psammobatis bergi Marini, 1932 (Elasmobranchii, Rajidae). Journal of Applied Ichthyology, 21(6): 504-510.

Sokal R.R. \& F.J. Rohlf. 1995. Biometry. 3a. ed. W.H. Freeman, San Francisco. 887 pp.

Treolar M.A., Laurenson L.J.B. \& J.D. Stevens. 2006. Descriptions of rajid egg cases from 
southeastern Australian waters. Zootaxa, 1231: 53-68.

Treude T., Kiel S., Linke P., Peckmann J. \& J.L. Goedert. 2011. Elasmobranch egg cases associated with modern and ancient cold seeps: a nursery for marine deep-water predators. Marine Ecology Progress Series, 437: 175-181.

Triola M.F. 2005. Introdução a estatística, 9a ed. Editora LTC, Rio de Janeiro. 656 p.

Vooren C.M. 1998. Elasmobrânquios Demersais. En: Seeliger U., Odebrecht C. \& Castello J.P. Os Ecossistemas Costeiro e Marinho do Extremo Sul do Brasil, pp. 157-162. Ecoscientia, Rio Grande.

Vooren, C.M. \& M.C. Oddone. 2019. La diversidad de los condrictios del extremo sur de Brasil: las especies, sus orígenes, y sus modos reproductivos. En: Muniz P., Brugnoli E., Venturini N., \& Conde P. Ciencias marino-costeras en el umbral del Siglo XXI Desafíos en Latinoamérica y el Caribe, pp.171-205. AGT Editor, México, DF.

Vooren C.M., Klippel S. \& A.B. Galina. 2005. Os elasmobrânquios das águas costeiras da plataforma sul. En: Vooren C.M. \& Klippel S. (Eds.). Ações para a conservação de tubarões e raias no sul do Brasil, pp. 113-127. Igaré, Porto Alegre.

Wourms J.P. 1977. Reproduction and development in Chondrichthyan fishes. American Zoologist, 17: 379-410.

Wourms, J.P. \& L.S. Demski. 1993. The reproduction and development of sharks, skates, rays and ratfishes: introduction, history, overview and future prospects. Environmental Biology of Fishes, 38: 7-21.

Wyffles J.T. 2009. Embryonic development of Chondrichthyan fishes: A Review. En: Kunz Y.W., Luer C.A. \& Kappor B.G. Enfield (Eds.). Development of non teleost fishes, pp1-103. Science Publishers, Enfield, NH, USA.

Zar J.H. 2010. Biostatistical Analysis, 5th ed. PrenticeHall/Pearson, Upper Saddle River, N.J. 944pp.

Fecha de Recepción: 23 de marzo de 2019 Fecha de Aceptación: 05 de noviembre de 2019 